\title{
Metabolite Profiling of Aquilaria malaccensis Leaf Extract Using Liquid Chromatography-Q-TOF-Mass Spectrometry and Investigation of Its Potential Antilipoxygenase Activity In-Vitro
}

\author{
Manar A. Eissa ${ }^{1, *}$, Yumi Z. H-Y. Hashim ${ }^{1, *}$, Dina M. El-Kersh ${ }^{2}$, Saripah S. S. Abd-Azziz ${ }^{3}{ }^{(1)}$, \\ Hamzah Mohd. Salleh ${ }^{1}$, Muhammad Lokman Md. Isa ${ }^{4}$ and Nor Malia Abd Warif ${ }^{5}$ \\ 1 International Institute for Halal Research and Training (INHART), International Islamic University Malaysia, \\ Gombak 53100, Selangor, Malaysia; hamzah@iium.edu.my \\ 2 Pharmacognosy Department, Faculty of Pharmacy, The British University in Egypt, Cairo 11837, Egypt; \\ dina.elkersh@bue.edu.eg \\ 3 Faculty of Science and Mathematics, Sultan Idris Education University, Tanjung Malim 35900, Perak, \\ Malaysia; saripah@fsmt.upsi.edu.my \\ 4 Department of Basic Medical Sciences for Nursing, Kulliyah of Nursing, International Islamic University \\ Malaysia, Kuantan 25200, Pahang, Malaysia; lokman@iium.edu.my \\ 5 Biomedical Sciences Program, Faculty of Health Sciences, Universiti Kebangsaan Malaysia, \\ Kuala Lumpur 50300, Malaysia; malia.warif@ukm.edu.my \\ * Correspondence: manareissa1210@gmail.com (M.A.E.); yumi@iium.edu.my (Y.Z.H.-Y.H.)
}

Received: 17 December 2019; Accepted: 30 January 2020; Published: 6 February 2020 updates

\begin{abstract}
The Aquilaria malaccensis species of the genus Aquilaria is an abundant source of agarwood resin and many bioactive phytochemicals. Recent data regarding the chemical constituents and biological activities of Aquilaria leaves led us to attempt to qualitatively profile the metabolites of Aquilaria malaccensis leaves from a healthy, noninoculated tree through phytochemical screening, GC-MS, and LC/Q-TOF-MS. The present work is also the first to report the antilipoxygenase activity of $A$. malaccensis leaves from healthy noninoculated tree and investigate its toxicity on oral mucosal cells. A total of 53 compounds were tentatively identified in the extract, some of which have been described in literature as exhibiting anti-inflammatory activity. A number of compounds were identified for the first time in the extract of $A$. malaccensis leaf, including quercetin, quercetin-O-hexoside, kaempferol-O-dirhamnoside, isorhamnetin- $O$-hexoside, syringetin- $O$-hexoside, myricetin, tetrahydroxyflavanone, hesperetin, sissotrin, and lupeol. The antilipoxygenase assay was used to determine the lipoxygenase (LOX) inhibitory potential of the extract, while a WST-1 assay was conducted to investigate the effect of the extract on oral epithelial cells (OEC). The extract implied moderate anti-LOX activity with $\mathrm{IC}_{50}$ value of $71.6 \mu \mathrm{g} / \mathrm{mL}$. Meanwhile, the cell viability of OEC ranged between $92.55 \%(10 \mu \mathrm{g} / \mathrm{mL})-76.06 \% \pm(100 \mu \mathrm{g} / \mathrm{mL})$ upon treatment, indicating some potential toxicity risks. The results attained encourage future studies of the isolation of bioactive compounds from Aquilaria malaccensis leaves, as well as further investigation on the anti-inflammatory mechanisms and toxicity associated with their use.
\end{abstract}

Keywords: Aquilaria malaccensis; agarwood; extract; LCMS; GCMS; anti-inflammatory; toxicity; OEC; WST-1

\section{Introduction}

Aquilaria (Thymelaeaceae) is an agarwood-producing genus that includes 21 species [1]. The Aquilaria species predominating in the literature are Aquilaria malaccensis (synonym to Aquilaria agallocha), 
Aquilaria sinensis, and Aquilaria crassna [2]. The A. malaccensis tree is geographically distributed mainly in Indomalesian rainforests, and is known for its production of agarwood resin. Its economically valuable fragrant resin led to illegitimate and irrational harvesting of the Aquilaria tree, causing a severe decline in their natural population. The tree is labeled as endangered, and is currently protected under CITES regulations and the IUCN Red List [1].

In addition to its commercial value, different parts of the tree have been investigated for their therapeutic effects [2]. Aquilaria leaves are consumed as a herbal tea drink in Indonesia [3], and were traditionally used in the treatment of trauma, constipation, headache, elevated blood pressure, and diabetes [3,4]. Scientific information on the bioactivities of $A$. malaccensis leaves in particular reported their ability to exhibit antimicrobial [3,5-7], antioxidant [3,6,8], antidiabetic [6], antiarthritic [9], hepatoprotective [10], antitrypanosomal [11], and potential anti-inflammatory [12] effects. Moreover, the leaf extract demonstrated the potential to improve fertility and induce embryogenesis [13], as well as increasing healthy sperm production [14]. Furthermore, a recent study [15] indicated the role of $A$. malaccensis leaves in the treatment of immune suppression-related disorders. The chemical constituents of the leaves of $A$. malaccensis are reportedly compounds like phenolic acids, benzophenones, xanthonoids, flavonoids, terpenoids, steroids, quinones, lignans, and fatty acids [2], in addition to hydroxyacetanilide [16]. The presence of multiple bioactive constituents in the leaves of A. malacensis earned it the potential to become a source for the development of natural therapy.

Inflammation is an adaptive response to noxious stimuli and conditions in order to protect the body tissues through a cascade of complex events that involves cellular and vascular reactions [17]. Yet, chronic unresolved inflammation leads to various chronic diseases such as Alzheimer's, cardiovascular disorders, and cancer [18]. Many types of herbs have been used traditionally for the treatment and management of inflammatory disorders [19]. Recently A. malaccensis leaves have been explored for their anti-inflammatory activity, and were reported to inhibit albumin denaturation in vitro $[9,12]$. However, other anti-inflammatory pathways ought to be investigated.

A. sinensis and A. crassna leaves have demonstrated that they can be consumed orally as herbal drinks without major toxicity concerns [4]. An A. malaccensis leaf extract was tested for its oral acute toxicity on Wistar albino rats and was found to be safe [15]. Nevertheless, additional studies are needed to gain a better understanding of the extract's toxicity.

The diverse pharmacological activities of $A$. malaccensis leaves have drawn increasing attention from researchers worldwide, and prompted the authors of this paper to characterize the ethanolic extract of $A$. malaccensis leaves from a healthy noninoculated tree using gas chromatography-mass spectroscopy (GC-MS) and high resolution liquid chromatography-quadrupole time-of-flight-mass spectrometry (LC/Q-TOF-MS), in order to evaluate its toxicity and potential antilipoxygenase activity.

\section{Materials and Methods}

\subsection{Sample, Chemicals, and Reagents}

Fresh leaves of a healthy noninoculated Aquilaria malaccensis tree were collected from a local plantation in Semenyih, Selangor. The leaves were identified according to their morphology and voucher specimen deposited at the KAED Herbarium at the International Islamic University Malaysia. Analytical grade (95\%) ethanol was purchased from Fisher Chemical. Methanol, Acetonitrile, and formic acid were provided by Sigma-Aldrich. Deionized water was used for LC/Q-TOF-MS analysis. Sodium phosphate buffer, soyabean lipoxygenase enzyme, sodium linoleic acid, Nordihydroguaiaretic acid (NDGA), and dimethyl sulfoxide (DMSO) were provided by FRIM (Forest Research Institute Malaysia). The OEC (abm ${ }^{\circledR}$ Cat. Number: T4074), WST-1 reagent and DMEM complete media were obtained from Nawah Scientific, Egypt. 


\subsection{Sample Preparation}

Leaves of $A$. malaccensis were washed and dried in a drying chamber at a temperature of $40{ }^{\circ} \mathrm{C}$ overnight. The sample was ground into a powder, $50 \mathrm{~g}$ of which was extracted with $95 \%$ ethanol. Excess ethanol was evaporated under reduced pressure at $40{ }^{\circ} \mathrm{C}$ using a rotary evaporator (Heidolph-instruments, Rotavapor, Germany). Dried ethanolic extract (3.25 g) was stored in a dry container until further analysis.

\subsection{Phytochemical Screening}

Qualitative chemical screening was conducted to test the presence of organic compounds such as alkaloids, phenols, tannins, steroids, triterpenoids, flavonoids, and saponins. Phytochemical screening tests were done using the procedures provided by [20]. The results of the phytochemical screening can provide information about the potential therapeutic uses of the sample.

\subsection{GC-MS}

The volatile constituents of the sample were analyzed using a gas chromatography system, the Agilent 7890A (Agilent Technologies Inc., Santa Clara, CA, USA) coupled with an Agilent 5975C quadrupole mass spectrometer and an auto sampler Hewlett Packard HP-5MS ultra inert silica capillary column $(30 \mathrm{~m} \times 0.25 \mathrm{~mm} ; 0.25 \mu \mathrm{m})$ [21]. The detected peaks from the total ion chromatography (TIC) and mass chromatograms were identified based on National Institute of Standards and Technology (NIST) 2008 mass spectral library.

\section{5. $L C / Q-T O F-M S$}

Samples were submitted to the Proteomics and Metabolomics lab, Cancer Children Hospital Egypt (CCHE) 57357, Cairo, Egypt. The sample was prepared by dissolving $50 \mathrm{mg}$ of the extract in $1 \mathrm{~mL}$ mobile phase working solution (MP-WS), i.e., Deionized Water, Methanol, and Acetonitrile in a ratio of 50:25:25 respectively. The mixture was vortexed for $2 \mathrm{~min}$ followed by ultra-sonication for $10 \mathrm{~min}$, and centrifuged for $5 \mathrm{~min}$ at 10,000 rpm. Then, $20 \mu \mathrm{L}$ stock $(50 / 1000 \mu \mathrm{L})$ was diluted with $1000 \mu \mathrm{L}$ reconstitution solvent. Finally, the injected concentration was $1 \mu \mathrm{g} / \mu \mathrm{L} ; 25 \mu \mathrm{L}$ of the sample was injected on the positive and negative mode along with injection of $25 \mu \mathrm{L}$ MP-WS as blank sample. The constituents of the extract were analyzed by using LC/Q-TOF-MS in both positive and negative modes. The analysis was carried out using a system equipped with a column (Waters, Xbridge C-18, $50 \mathrm{~mm} \times 2.1 \mathrm{~mm}, 3 \mu \mathrm{m}$ particle size) operated at $40^{\circ} \mathrm{C}$, and precolumn (In-Line filter disks, Phenomenex, $0.5 \mu \mathrm{m} \times 3.0 \mathrm{~mm}$ ). The mobile phases were solvent A (Deionized water containing $0.1 \%$ Formic acid) for positive mode, solvent $\mathrm{B}$ ( $5 \mathrm{~mm}$ ammonium formate buffer $\mathrm{pH} 8$ containing $1 \%$ methanol) for negative mode, and solvent $C(100 \%$ acetonitrile) for both positive and negative modes. The following gradient elution at a rate of $0.3 \mathrm{~mL} / \mathrm{min}$ was used: isocratic $90 \% \mathrm{~A}$ or $\mathrm{B}$ and $10 \% \mathrm{C}(0-1 \mathrm{~min})$, linear from $90 \%$ to $10 \%$ A or B to $10 \%$ to $90 \%$ C (1.1-20.9 min), isocratic $10 \%$ A or B and $90 \%$ C (21-25 min), and finally, isocratic $90 \% \mathrm{~A}$ or B and $10 \% \mathrm{C}$ (25.1-28 min). The injection volume was $10 \mu \mathrm{L}$. Only compounds having PCDL Score $>80$ and a mass error within 5 ppm of the known mass of the detected molecules were tentatively identified based on their masses and by comparing their fragmentation patterns obtained by Peakview software (SCIEX, Framingham, MA, USA) with fragmentation patterns of similar compounds in reference literature and in the MassBank i.e., MoNA (Massbank of North America), HDMB (Human Metabolome Database) and NIST (National Institute of Standards and Technology) libraries.

\subsection{Antilipoxygenase Assay}

Lipoxygenase inhibiting activity was measured by slightly modifying the spectrometric method developed by [22]. In the assay protocol, $160 \mu \mathrm{L}$ of $100 \mathrm{~mm}$ sodium phosphate buffer ( $\mathrm{pH}$ 8.0), $10 \mu \mathrm{L}$ of test-compound solution, and $20 \mu \mathrm{L}$ of soybean lipoxygenase enzyme solution were mixed and 
incubated for $10 \mathrm{~min}$ at $25^{\circ} \mathrm{C}$. The enzyme reaction was initiated by the addition of $10 \mu \mathrm{L}$ sodium linoleic acid (substrate) solution, and was incubated once more in spectrophotometer at $25{ }^{\circ} \mathrm{C}$ for $10 \mathrm{~min}$. NDGA was used as reference standard. DMSO was used as negative control. The extract and the reference standard were dissolved in DMSO. All the reactions were performed in triplicate in a 96-well micro-plate, and the absorbance was read at $234 \mathrm{~nm}$ in a microplate reader. The percentage inhibition was calculated from the following equation:

$$
\% \text { inhibition }=(\text { O.D of control }- \text { O.D of sample/O.D of control }) \times 100
$$

\subsection{Toxicity Screening Assay}

The cell viability of oral epithelial cells (OEC) was tested by WST-1 assay using Abcam ${ }^{\circledR}$ Kit (ab155902 WST-1 Cell Proliferation Reagent). The assay is a colorimetric assay that measures the cell viability based on the cleavage of tetrazolium salts by mitochondrial dehydrogenase in viable cells. Cells were maintained in DMEM media supplemented with $100 \mathrm{mg} / \mathrm{mL}$ of streptomycin, $100 \mathrm{units} / \mathrm{mL}$ of penicillin, and $10 \%(\mathrm{v} / \mathrm{v})$ of heat-inactivated fetal bovine serum. The cells were incubated in $5 \%$ $\mathrm{CO}_{2}$ at $37{ }^{\circ} \mathrm{C}$ for $24 \mathrm{~h}$. A stock solution of the extract $(1000 \mathrm{mg} / \mathrm{mL})$ was prepared in serum-free media containing $0.1 \%$ DMSO (v/v), and serial dilutions of $10 \mu \mathrm{g} / \mathrm{mL}$ and $100 \mu \mathrm{g} / \mathrm{mL}$ were obtained by dilution with serum-free media. The toxicity screening assay was performed by first seeding $3 \times 10^{3}$ cells (aliquots of $50 \mu \mathrm{L}$ cell suspension) in 96-well plate prior to incubation for $24 \mathrm{~h}$. The old media was then discarded and the cells were treated with an aliquot of $50 \mu \mathrm{L}$ media containing extract in a concentration of $10 \mu \mathrm{g} / \mathrm{mL}$ and $100 \mu \mathrm{g} / \mathrm{mL}$, respectively. The control group comprised media and $0.1 \%$ DMSO. After $48 \mathrm{~h}, 10 \mu \mathrm{L}$ WST-1 reagent was added. After $1 \mathrm{~h}$, the absorbance was measured at $\lambda=450 \mathrm{~nm}$ using BMG LABTECH ${ }^{\circledR}$-FLUOstar Omega microplate reader (Allmendgrün, Ortenberg, Germany). The method was adopted from $[23,24]$ with slight modifications. Toxicity results were obtained from three experiments with three well plates for each concentration in a separate 96-well plate. The cell viability was calculated using the equation:

Cell viability $\%=[($ Abs. of Treatment - Abs. of Blank $) /($ Abs. of Control - Abs. of Blank $)] * 100$

\subsection{Statistical Methods}

Data are presented as mean \pm standard deviation of three independent experiments.

\section{Results and Discussion}

\subsection{Phytochemical Screening}

The results presented in Table 1 show that the ethanolic extract of $A$. malaccensis leaves contains flavonoids, saponins, steroids, terpenoids, tannins, and phenols, but is free from alkaloids. The results are consistent with a previous study [25]. However, other research has reported the presence of alkaloids in $A$. malaccensis leaves $[7,26,27]$. This can be attributed to the different geographical origin of the sample, since environmental factors such as land and weather play a role in phytochemical profile variations [8], or due to the utilization of different extracting solvents or extracting parameters. It has been pointed out that the type and age of organ are among the factors that affect the occurrence of phytochemicals [3]. Phenolic compounds, flavonoids, sterols, and terpenoids have been closely related to anti-inflammatory activity. 
Table 1. Summary of the phytochemical screening of the ethanolic extract of $A$. malaccensis leaves.

\begin{tabular}{cccc}
\hline Phytochemical & Test & Result & Observation \\
\hline Flavonoids & NaOH test & + & Yellow color \\
\hline & Shinoda test & + & Orange red color \\
\hline Saponins & Pb acetate test & + & Formation of yellow ppt \\
\hline Steroids & Froth Test & + & Formation of froth \\
\hline Terpenoids & Liebermann-Burchard test & + & Change in color \\
\hline Tannins & Salkowski test & + & Reddish brown color \\
\hline \multirow{2}{*}{ Alkaloids } & Ferric chloride test & + & Dark green color \\
\hline Phenols & Dragendroff's test & - & No reddish brown ppt \\
\hline & Mayer's test & - & No creamy ppt \\
\hline
\end{tabular}

\subsection{GC-MS}

Table 2 shows the results of the identified compounds in the underivatized crude leaf ethanolic extract. A total of 20 compounds were identified, with the major constituents being the monoterpene (Bicyclo [3.1.1] heptane, 2,6,6-trimethyl-, [1R-(1.alpha.,2.beta.,5.alpha.)]), the acyclic diterpene (Phytol), and the fatty acid (Hexadecanoic acid), as shown in Figure 1. Both phytol and hexadecanoic acid were detected in the GC-MS analysis performed by [26]. In addition, fatty acids, esters, and aliphatic compounds were also observed. Of the identified compounds, hexadecanoic acid and phytol are known for their anti-inflammatory activity, according to [28,29]. Resemblances and diversities occur in comparative GC-MS results in the literature, depending on the species, the extraction method, the extracted part of the tree, and environmental factors. For instance, sterols were not observed in this study, while they were present in the GC-MS analysis of agarwood oil obtained from A. malaccensis wood [30]. According to [31], sterols occur in GC-MS analysis after sample derivatization. Squalene has also been identified previously in Aquilaria leaves extracts obtained by hydrodistillation, and by methanolic and $n$-hexane extraction [32]. In the GC-MS analysis of a Borneo A. malaccensis leaf ethanolic extract performed by [26], the presence of alkaloids predominated, in contrast to the present study, where only traces of imidazole were noted.

Abundance

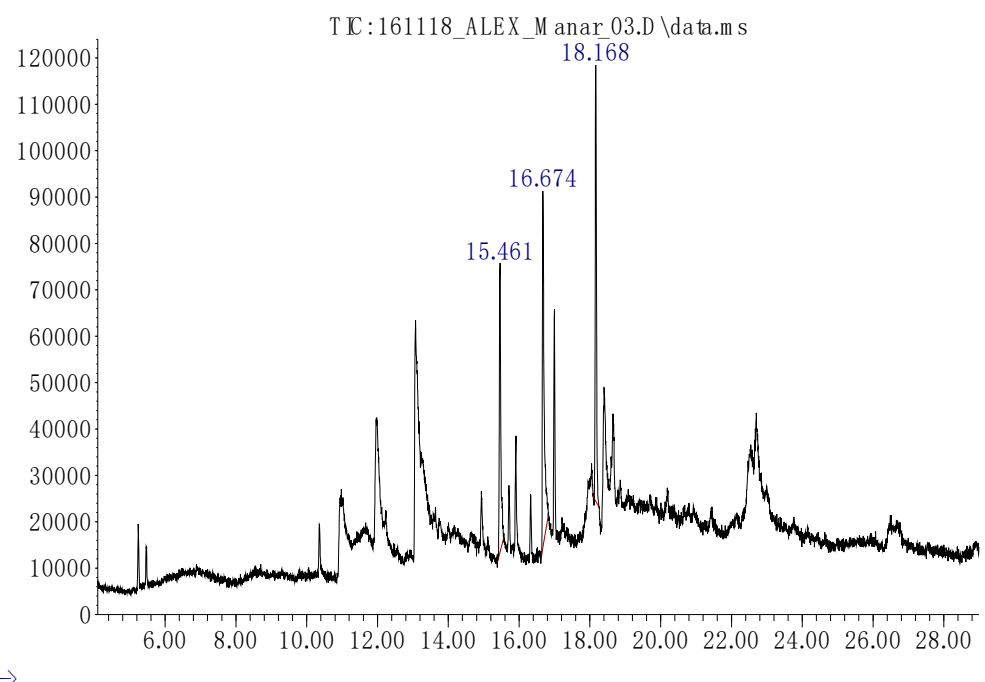

$\mathrm{T}$ in $\mathrm{e} \rightarrow$

Figure 1. GC-MS chromatogram of A. malaccensis ethanolic leaf extract. 
Table 2. Chemical constituents identified in ethanolic extract of $A$. malaccensis by GCMS

\begin{tabular}{|c|c|c|c|c|c|}
\hline PK & RT & Area Pct & Library/ID & Ref & Qual \\
\hline 1 & 5.2411 & 1.7647 & 3,4-dihydroxy-3,4-dimethylhexane-2,5-dione & 41,472 & 40 \\
\hline 2 & 5.4741 & 1.1581 & $\begin{array}{c}\text { N-Hydroxycarbamic } \\
\text { acid,2-(isopropoxycarbonylamino)ethyl ester }\end{array}$ & 66,362 & 25 \\
\hline 3 & 6.8827 & 0.3698 & Trimethylurea & 4204 & 27 \\
\hline 4 & 8.699 & 0.1852 & 2R,3S-9-[1,3,4-Trihydroxy-2-butoxymethyl]guanine & 131,542 & 17 \\
\hline 5 & 9.991 & 0.1905 & 1H-Imidazole-4-acrylamide & 16,605 & 38 \\
\hline 6 & 10.3564 & 1.7308 & 1,1,3,3-Tetramethyl-1,3-disiletane & 20,576 & 38 \\
\hline 7 & 10.6 & 0.2157 & 3,4,5,6,7-pentahydroxy-1-phenoxyheptan-2-one & 132,320 & 50 \\
\hline 8 & 10.7853 & 0.2232 & methyl N-amino-N-methylcarbamodithioate & 15,931 & 35 \\
\hline 9 & 10.9601 & 3.438 & N-Butylacetamide & 7803 & 37 \\
\hline 10 & 11.9556 & 3.5325 & 4-Cyclopropylmethylbenzonitrile & 29,225 & 43 \\
\hline 11 & 13.0729 & 17.2609 & 4-Methyldecane & 28,433 & 22 \\
\hline 12 & 14.9368 & 1.9729 & 5-Methyl-2-(1-methylethylidene)cyclohexan-1-one oxime & 35,916 & 27 \\
\hline 13 & 15.4611 & 10.8317 & Pinane & 17,016 & 50 \\
\hline 14 & 15.7152 & 2.0621 & 1,2-Dipentylcyclopropene & 45,727 & 50 \\
\hline 15 & 15.9112 & 3.0504 & 1-Ethynyl-1-cyclohexanol & 10,508 & 38 \\
\hline 16 & 16.3242 & 2.0009 & Methyl hexadecanoate & 119,407 & 93 \\
\hline 17 & 16.6684 & 17.9539 & n-Hexadecanoic acid & 107,547 & 90 \\
\hline 18 & 16.9967 & 6.1465 & Ethyl hexadecanoate & 131,288 & 98 \\
\hline 19 & 18.167 & 15.9946 & Phytol & 141,393 & 91 \\
\hline 20 & 18.4 & 9.9175 & 9-octadecenoic acid & 129,341 & 94 \\
\hline
\end{tabular}




\section{3. $L C / Q-T O F-M S$}

LC/Q-TOF-MS represents an important approach to identifying unknown constituents in plant extracts. The chemical constituents of $A$. malaccensis leaves extracted with $95 \%$ ethanol were analyzed via LC/Q-TOF-MS in both positive and negative ionization modes, since flavonoid fragmentations can be recorded on positive and negative ion modes [33]. However, the negative ion mode in the current study provided a wider range of metabolites than the positive ion mode. A total of 53 peaks were tentatively identified as belonging to various classes, including phenolic acids (5), benzophenones (4), flavonoids (27), xanthones (2), sterols (2), terpenoids (5), coumarins (1), lignans (1), fatty acids (2), and tocopherols (1), in addition to three unknown compounds, as shown in Table 3. The LC/Q-TOF-MS peaks chromatograms of both negative and positive modes are shown in Figure 2.

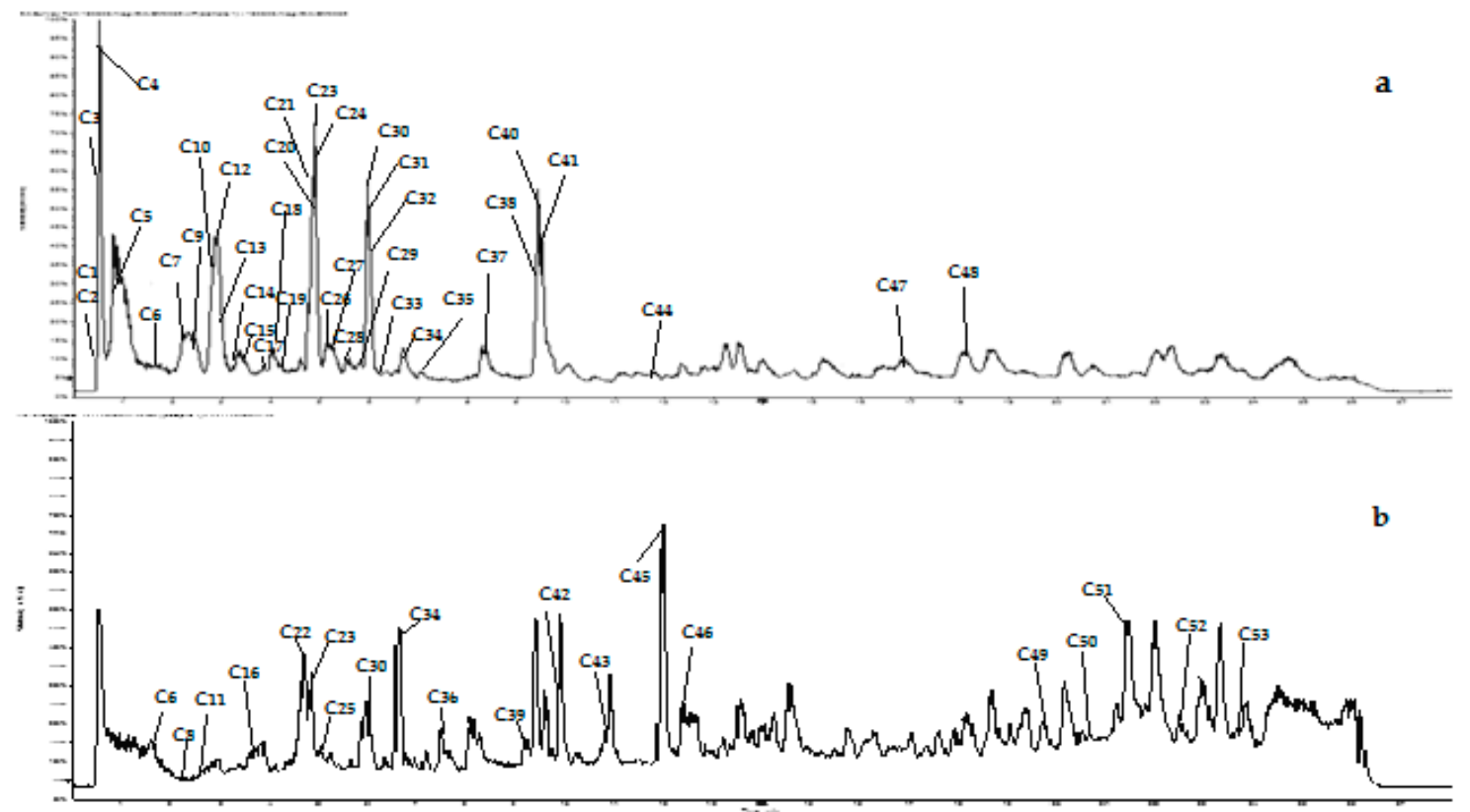

Figure 2. LC/Q-TOF-MS Total Ion Chromatogram (TIC) of the ethanolic extract of A. malaccensis leaf on the negative ion mode (a) and positive ion mode (b). Chromatographic conditions are presented in the materials and methods section. The tentatively identified compounds are listed in Table 3.

\subsubsection{Phenolic Acids}

Prior studies have revealed the existence of multiple phenolic acids in Aquilaria leaves [2]. In the present study, four new phenolic acids were introduced regarding the chemical constituents of Aquilaria species. The MS/MS spectra of peaks C1 (m/z 133.0152, $\left.\mathrm{C}_{4} \mathrm{H}_{5} \mathrm{O}_{5}{ }^{-}\right), \mathrm{C} 2\left(\mathrm{~m} / \mathrm{z} 117.0182, \mathrm{C}_{4} \mathrm{H}_{5} \mathrm{O}_{4}{ }^{-}\right)$, $\mathrm{C} 3\left(\mathrm{~m} / \mathrm{z} 153.0199, \mathrm{C}_{7} \mathrm{H}_{5} \mathrm{O}_{4}{ }^{-}\right)$, and $\mathrm{C} 5\left(\mathrm{~m} / \mathrm{z} 163.0390, \mathrm{C}_{9} \mathrm{H}_{7} \mathrm{O}_{3}{ }^{-}\right)$all exhibited a fragmentation pattern of $\left[\mathrm{M}-\mathrm{H}-\mathrm{CO}_{2}\right]^{-}$, followed by $\left[\mathrm{M}-\mathrm{H}-\mathrm{H}_{2} \mathrm{O}\right]^{-}$on negative ionization mode due to the elimination of $\mathrm{CO}_{2}$ group ( $-44 \mathrm{Da}$ ) and $\mathrm{H}_{2} \mathrm{O}$ molecule $(-18 \mathrm{Da})$ from the deprotonated precursor ion (Supplmentaray Figures S1-S4). The compounds were identified as Malic acid (C1), Succinic acid (C2), Protocatechuic acid (C3), and Coumaric acid (C5), and their MS/MS spectra were reported by [34]. The glycosylated phenolic acid Glucopyranosyl sinapate (C7) $\left[\mathrm{m} / \mathrm{z} 385.1896, \mathrm{C}_{17} \mathrm{H}_{21} \mathrm{O}_{10^{-}}\right]$was assigned to peak (C7); its fragmentation was described previously by [35] (Supplementary Figure S5). Protocatechuic acid (C3) was previously identified in A. sinensis leaves and demonstrates antidiabetic activity [36].

\subsubsection{Benzophenones}

A total of four benzophenones were identified in the sample. A benzophenone aglycone occurred at peak $\mathrm{C} 13$, while three other benzophenone glycosides occurred at peaks $\mathrm{C} 12, \mathrm{C} 23$, and C30. The precursor ion $[\mathrm{M}-\mathrm{H}]^{-}$of peak $\mathrm{C} 13\left(\mathrm{~m} / \mathrm{z} 245.0472, \mathrm{C}_{13} \mathrm{H}_{9} \mathrm{O}_{5}{ }^{-}\right)$produced fragments at $\mathrm{m} / \mathrm{z}$ 
$151\left[\mathrm{M}-\mathrm{H}-\mathrm{C}_{6} \mathrm{H}_{6} \mathrm{O}\right]^{-}$and $\mathrm{m} / \mathrm{z} 107\left[\mathrm{M}-\mathrm{H}-\mathrm{C}_{6} \mathrm{H}_{6} \mathrm{O}-\mathrm{CO}_{2}\right]^{-}$, which is a common fragmentation pattern of benzophenones, as mentioned in [37]. The mass, together with its produced fragment ions, suggest that C13 is Iriflophenone [38] (Supplementary Figure S6), which was isolated earlier from A. sinensis leaves and has demonstrated significant anti-inflammatory activity [39].

Peaks C12, C23, and C30 presented a significant fragment ion at $\mathrm{m} / \mathrm{z} 245$, which is the same as compound $\mathrm{C} 13$, leading us to speculate that the three compounds are Iriflophenone derivatives. The product ion of peak $\mathrm{C} 12\left(\mathrm{~m} / \mathrm{z} 391.1029, \mathrm{C}_{19} \mathrm{H}_{19} \mathrm{O}_{9}{ }^{-}\right)$occurred at $\mathrm{m} / \mathrm{z} 245$ due to cleavage of deoxyhexose moiety [M-H-146] ${ }^{-}$. This suggests that $\mathrm{C} 12$ is possibly Iriflophenone-2-O- $\alpha$-L-rhamnopyranoside (Supplementary Figure S7). Similarly, peak $\mathrm{C} 23\left(\mathrm{~m} / \mathrm{z} 433.1136, \mathrm{C}_{21} \mathrm{H}_{21} \mathrm{O}_{10}{ }^{-}\right.$) exhibited a mass is higher than Iriflophenone by $188 \mathrm{Da}$, supporting the identification of the compound as Iriflophenone, [2-(2-O-actyA-L-Rhamnopyranosyl) oxy] (Supplementary Figure S8a).The compound also occurred on the positive ion mode at $\mathrm{m} / \mathrm{z} 435.1296$ (Supplementary Figure S8b). Aquilarisinin is another Iriflophenone derivative that was assigned to peak $\mathrm{C} 30\left(\mathrm{~m} / \mathrm{z} 553.1350, \mathrm{C}_{25} \mathrm{H}_{29} \mathrm{O}_{14}{ }^{-}\right)$. Product ions occurred at $\mathrm{m} / \mathrm{z} 391$ and $\mathrm{m} / \mathrm{z} 245$ due to consecutive loss of hexose (-162 Da) and deoxyhexose (-146 Da) moiety (Supplementary Figure S9a). The presence of the compound was affirmed by its occurrence at $m / z 555.1508\left(\mathrm{C}_{25} \mathrm{H}_{31} \mathrm{O}_{14}{ }^{+}\right)$on the positive ion mode (Supplementary Figure S2b). The fragmentation pattern of Aquilarisinin is proposed in Figure 3. It is worth noting that the fragmentation patterns of C12 and C23 were identified earlier in a LC-MS analysis of A. sinensis leaves extract performed by [38]. Aquilarisinin was also reported in $A$. sinensis leaves as an $\alpha$-glucosidase inhibitor [40].

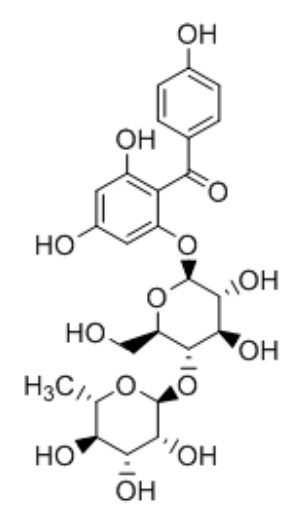

Chemical Formula: $\mathrm{C}_{6} \mathrm{H}_{10} \mathrm{O}_{5}{ }^{\circ-}$
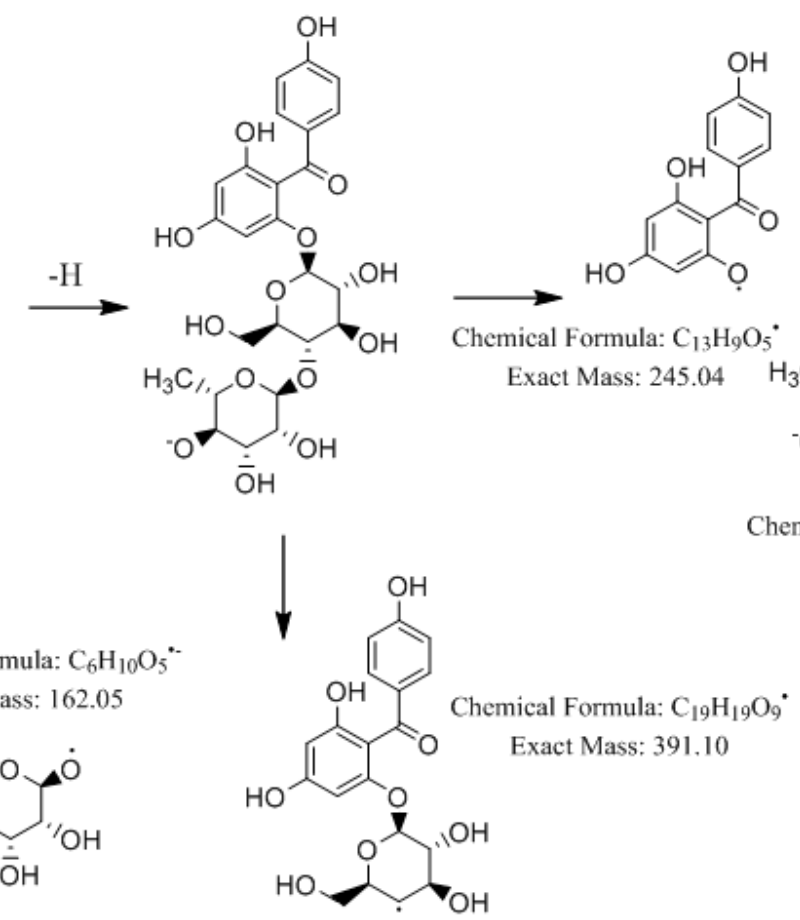

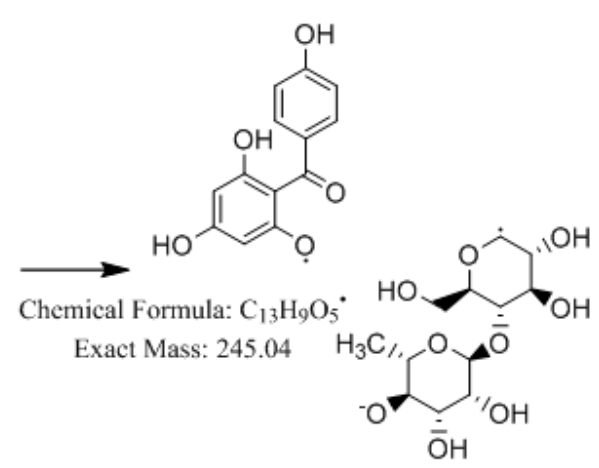

Chemical Formula: $\mathrm{C}_{12} \mathrm{H}_{20} \mathrm{O}_{9}{ }^{*-}$ Exact Mass: 308.11

Figure 3. Fragmentation pattern of Aquilarisinin on negative ion mode.

\subsubsection{Flavonoids}

In the ethanolic extract under study, flavonoids occurred predominately over other bioactive compounds. Flavonoids are among the most common phenolic compounds existing in nature. Flavonoid aglycones consist of aromatic rings $\mathrm{A}$ and $\mathrm{B}$ joined by ring $\mathrm{C}$. The substitution on ring $\mathrm{C}$ determines the type of the aglycone, i.e., flavanol, flavonol, flavone, isoflavone, and flavanone, as shown in Figure 4. The common features of flavonoid aglycones fragmentation is the production of fragment ions as a result of the cleavage of $\mathrm{CH}_{3}(-15 \mathrm{Da}), \mathrm{H}_{2} \mathrm{O}(-18 \mathrm{Da}), \mathrm{CO}(-28 \mathrm{Da}), \mathrm{CH}_{2} \mathrm{O}$ $(-30 \mathrm{Da})$, and $\mathrm{CO}_{2}(-44 \mathrm{Da})$, and a series of Retro-Diels-Alder (RDA) fragmentation reactions [41]. 
Fragmentation pathways have been observed in this study of flavonoid derivatives that occur in plants, specifically, flavonoid-O-glycosides and flavonoid-C-glycosides. In case of flavonoids-O-glycosides, the major fragment is produced due to the loss of hexose $[\mathrm{M} \pm \mathrm{H}-162]^{ \pm}$, deoxyhexose $[\mathrm{M} \pm \mathrm{H}-146]^{ \pm}$, dideoxyhexoside $[\mathrm{M} \pm \mathrm{H}-130]^{ \pm}$, or pentose $[\mathrm{M} \pm \mathrm{H}-132]^{ \pm}$sugar moieties, and an ion that represents the aglycone [33]. On the other hand, a flavonoids- $\mathrm{C}$-glycosides fragmentation pattern results from the loss of the water molecule $[\mathrm{M} \pm \mathrm{H}-18]^{ \pm}$, cross-ring cleavages of sugar units including $[\mathrm{M} \pm \mathrm{H}-120 / 90]^{ \pm}$ for C-hexoside, $[\mathrm{M} \pm \mathrm{H}-104 / 74]^{ \pm}$for $\mathrm{C}$-deoxyhexoside or $[\mathrm{M} \pm \mathrm{H}-90 / 60]^{ \pm}$for $\mathrm{C}$-pentoside, and ions corresponding to the aglycones, plus the remaining sugars [33].<smiles>OC1Cc2ccccc2OC1C1=CCCC=C1</smiles>

Flavanol<smiles>O=c1c(O)c(-c2ccccc2)oc2ccccc12</smiles>

Flavanol<smiles>O=C1CC(c2ccccc2)Oc2ccccc21</smiles>

Flavanone<smiles>O=c1cc(-c2ccccc2)oc2ccccc12</smiles>

Flavone<smiles>O=c1c(-c2ccccc2)coc2ccccc12</smiles>

Isoflavone

Figure 4. Structures of major flavonoid backbones.

- Flavanols

Peak (C6) was identified on both negative and positive ionization modes as Catechin $(\mathrm{m} / \mathrm{z}$ 289.0739/291.0896 $\left.[\mathrm{M} \pm \mathrm{H}]^{ \pm}, \mathrm{C}_{15} \mathrm{H}_{13} \mathrm{O}_{6}{ }^{-} / \mathrm{C}_{15} \mathrm{H}_{15} \mathrm{O}_{6}{ }^{+}\right)$. In the negative mode, $\mathrm{C} 6$ yielded fragment ions at $m / z 271\left[\mathrm{M}-\mathrm{H}-\mathrm{H}_{2} \mathrm{O}\right]^{-}$after the loss of $18 \mathrm{Da}$, and at $m / z 245\left[\mathrm{M}-\mathrm{H}-\mathrm{CH}_{2} \mathrm{CHOH}\right]^{-}$after the loss of $44 \mathrm{Da}$. The produced ion at $m / z 179$ [M-H-dihydroxybenzene moiety] $]^{-}$was confirmed by the presence of $\mathrm{m} / \mathrm{z}$ 109 [M-H-179] ${ }^{-}$. Also, $\mathrm{m} / \mathrm{z} 137$ occurred after the cleavage of ring $\mathrm{C}$ by retro-Diels-Alder (RDA) reaction, which was also confirmed by the presence of the ion at $m / z 151$ [42] (Supplementary Figure S10a). Likewise, the protonated precursor ion was subjected to heterocyclic ring fission (HRF) that resulted in production of fragment ion $\mathrm{m} / \mathrm{z}$ 147. In addition, the protonated precursor ion was also subjected to heterocyclic ring fission (HRF), benzofuran ring fission (BFF), and Retro-Diels Alder cleavage (RDA), that resulted in the production of ions at $m / z$ 165, $m / z$ 123, and $m / z 139$ [43] (Supplementary Figure S10b). Catechins are expected to be present in A. malaccensis leaves as a major constituent of tea popularly consumed in Asian countries [3]. For instance, catechin derivatives such as epigallocatechin gallate and epicatechin gallate were previously isolated from A. crassna leaves [44]. Recent studies have revealed that catechins exhibit anti-inflammatory activity via wide range of mechanisms $[45,46]$.

\section{- Flavonols}

Peak $\mathrm{C} 29\left(\mathrm{~m} / \mathrm{z}\right.$ 301.0360, $\left.\mathrm{C}_{15} \mathrm{H}_{9} \mathrm{O}_{7}^{-}\right)$demonstrated further neutral losses of $28 \mathrm{Da}(-\mathrm{CO}), 122 \mathrm{Da}$ (-ring $\mathrm{B}$ ) and $150 \mathrm{Da}$ (-ring $\mathrm{B}$ and $-\mathrm{CO}$ ) to produce the fragment ions of the $[\mathrm{M}-\mathrm{H}-\mathrm{CO}]^{-}$ion at $\mathrm{m} / \mathrm{z}$ 273, $[\mathrm{M}-\mathrm{H}-\text { ring B }]^{-}$ion at $\mathrm{m} / \mathrm{z} 179$ and $[\mathrm{M}-\mathrm{H}-\text { ring B-CO }]^{-}$ion at $\mathrm{m} / \mathrm{z} 151$. Peak C15 $(\mathrm{m} / \mathrm{z} 463.0889$, $\mathrm{C}_{21} \mathrm{H}_{19} \mathrm{O}_{12}{ }^{-}$) demonstrated similar fragmentation pattern as observed in peak $\mathrm{C} 29$, but with an additional ion resulting from the loss of the hexoside group (-162 Da). Based on a comparison between this fragmentation pattern and the MS/MS spectra in the previous studies [47], peak C29 was identified as quercetin (Supplementary Figure S11), while peak C15 was identified as quercetin-O-hexoside (Supplementary Figure S12). Peak C10 (m/z 461.0711, $\left.\mathrm{C}_{21} \mathrm{H}_{17} \mathrm{O}_{12}{ }^{-}\right)$and $\mathrm{C} 33(\mathrm{~m} / \mathrm{z}$ $593.1518, \mathrm{C}_{27} \mathrm{H}_{29} \mathrm{O}_{15}{ }^{-}$) both produced deprotonated aglycone fragment at $\mathrm{m} / z 285$, which corresponds to kaempferol aglycone. The precursor ion of $\mathrm{C} 10$ produced the fragment ions at $m / z 417$ [M-H-44] $]^{-}$ and $m / z 285$ [M-H-176] $]^{-}$; this was attributed to the loss of $\mathrm{CO}_{2}$ and glucuronic acid, respectively. $\mathrm{C} 10$ is most likely kaempferol-O-glucuronide (Supplementary Figure S13), as proposed by [48]. The product ion of $\mathrm{C} 33$ occurred at $\mathrm{m} / \mathrm{z} 285$ [M-H-308] $^{-}$, and the compound was tentatively identified 
as kaempferol-O-neohesperidoside (Supplementary Figure S14). The fragmentation pattern of the compound was provided by [49]. Peak C22 (m/z 579.1703, $\left.\mathrm{C}_{27} \mathrm{H}_{31} \mathrm{O}_{14}{ }^{+}\right)$was identified on the positive ion mode as kaempferol-O-dirhamnoside based on the occurrence of ion at $m / z 285$, which suggests the loss of two deoxyhexose moieties (Supplementary Figure S15). The fragmentation pattern was also reported by [50]. Peaks C18 (m/z 477.1034, $\left.\mathrm{C}_{22} \mathrm{H}_{21} \mathrm{O}_{12}{ }^{-}\right)$and $\mathrm{C} 32\left(\mathrm{~m} / \mathrm{z} 623.1359, \mathrm{C}_{28} \mathrm{H}_{31} \mathrm{O}_{16}{ }^{-}\right)$ exhibited a product ion at $\mathrm{m} / \mathrm{z} 315$, which resembles isorhamnetin aglycone. The occurrence of the abundant ion $[\mathrm{M}-\mathrm{H}-162]^{-}$in the fragmentation pattern of $\mathrm{C} 18$ suggests the loss of hexoside moiety. Nevertheless, the fragmentation pattern of C32 showed the major fragment ion at $[\mathrm{M}-\mathrm{H}-308]^{-}$. Accordingly, these two peaks were identified as isorhamnetin-O-hexoside (Supplementary Figure S16) and isorhamnetin-O-rutinoside (Supplementary Figure S17), respectively. This identification is supported by the previous suggestion of their fragmentation patterns by [51]. Peak C19 is another flavonol-O-hexoside $\left(\mathrm{m} / \mathrm{z} 507.1489, \mathrm{C}_{23} \mathrm{H}_{23} \mathrm{O}_{13}{ }^{-}\right)$that showed a daughter fragment ion at $\mathrm{m} / \mathrm{z} 345$ caused by the cleavage of hexose unit and is corresponding to syringetin aglycone, which suggests that C19 is syringetin-O-hexoside [52] (Supplementary Figure S18). The MS/MS spectra of peak C20 ( $\mathrm{m} / \mathrm{z} 317.0315$, $\mathrm{C}_{15} \mathrm{H}_{9} \mathrm{O}_{8}{ }^{-}$) presented two major fragment ions at $\mathrm{m} / \mathrm{z} 179$ [M-ring $\left.\mathrm{A}\right]^{-}$and $\mathrm{m} / \mathrm{z} 151\left[\mathrm{M}-\mathrm{H}-\right.$-ring $\mathrm{B}^{-}$ which result from typical RDA reaction in flavonol aglycones [41]. A similar fragmentation pattern was observed in [53]; the compound was tentatively characterized as myricetin (Supplementary Figure S19). It is worth noting that the mentioned flavonols were identified in Aquilaria for the first time, to the best of our knowledge.

- Flavanones

Three flavanones were detected in the sample, namely, peak $\mathrm{C} 27\left(\mathrm{~m} / z 287.0579, \mathrm{C}_{15} \mathrm{H}_{11} \mathrm{O}_{6}{ }^{-}\right)$, peak $\mathrm{C} 35\left(\mathrm{~m} / \mathrm{z} 301.0588, \mathrm{C}_{16} \mathrm{H}_{13} \mathrm{O}_{6}{ }^{-}\right)$, and peak $\mathrm{C} 38\left(\mathrm{~m} / \mathrm{z} 285.0774, \mathrm{C}_{16} \mathrm{H}_{13} \mathrm{O}_{5}{ }^{-}\right)$. The tentative identification of C27 as tetrahydroxyflavanone is based on the fragmentation pathway, as shown by [54], that include the cleavage of ring A at $m / z 151$ and ring B at $m / z 135$ (Supplementary Figure S20). Hesperetin flavanone was assigned to peak $\mathrm{C} 35$, and the precursor ion demonstrated a fragment ion at $\mathrm{m} / \mathrm{z} 286$ caused by the loss of one methyl group ( $-15 \mathrm{Da}$ ) (Supplementary Figure S21). The fragmentation pattern of hesperetin was reported by $[55,56]$. C38 exhibited fragmentation ion at $\mathrm{m} / \mathrm{z} 165$ caused by breakdown of ring $B$ in addition to $\mathrm{m} / \mathrm{z} 119$ due to the cleavage of ring $C$ followed by another ion at $\mathrm{m} / \mathrm{z} 93$ due to subsequent loss of ethynyl group, which suggests that C38 may be sakuranetin (Supplementary Figure S22), which is supported by similar fragmentation pattern displayed by [57]. Sakuranetin was previously reported in $A$. sinensis stem barks to express anti-inflammatory activity through noticeable inhibition of superoxide anion generation and elastase release [58]. The other detected flavanones (i.e., tetrahydroxyflavanone and hesperetin) were detected in Aquilaria for the first time.

\section{- Flavones}

The flavone aglycone luteolin was assigned to peak $\mathrm{C} 28\left(\mathrm{~m} / \mathrm{z} 285.0409, \mathrm{C}_{15} \mathrm{H}_{9} \mathrm{O}_{6}{ }^{-}\right)$, and was identified based on its fragmentation pattern that showed an ion at $\mathrm{m} / z 133$ caused by the cleavage of ring B (Supplementary Figure S23). The fragmentation pattern of Luteolin was proposed earlier by [57]. Luteolin was formerly isolated from $A$. sinensis flowers [59] and $A$. sinensis leaves, where it revealed potent anti-inflammatory activity [39]. Nevertheless, its glycoside derivative occurred at peak $\mathrm{C} 17\left(\mathrm{~m} / \mathrm{z} 447.0946, \mathrm{C}_{21} \mathrm{H}_{19} \mathrm{O}_{11}{ }^{-}\right)$and produced an abundant fragment ion at $\mathrm{m} / \mathrm{z} 285$ [M-H-Hexose] $]^{-}$, which suggests that $\mathrm{C} 17$ is luteolin-O-hexoside (Supplementary Figure S24), as formerly reported by [51]. C34 was annotated on the negative mode $\left(\mathrm{m} / z 269.0473, \mathrm{C}_{15} \mathrm{H}_{9} \mathrm{O}_{5}{ }^{-}\right)$, and is characterized by the presence of unique fragment ion at $\mathrm{m} / \mathrm{z} 149$ characteristic for apigenin aglycone according to [51] (Supplementary Figure S25a). The presence of apigenin is also confirmed on the positive ion mode $\left(\mathrm{m} / \mathrm{z} 271.0601, \mathrm{C}_{15} \mathrm{H}_{11} \mathrm{O}_{5}{ }^{+}\right)$, whereas its fragmentation pattern matches with the MS/MS spectra of apigenin reported by [60] (Supplementary Figure S25b). Apigenin was isolated earlier from A. sinensis flowers [59]. However, the identification of peak $\mathrm{C} 21\left(\mathrm{~m} / \mathrm{z} 431.0995, \mathrm{C}_{21} \mathrm{H}_{19} \mathrm{O}_{10}{ }^{-}\right)$relied on the 
formation of ion fragments at $\mathrm{m} / \mathrm{z} 311$ caused by the loss of $90 \mathrm{Da}$, which corresponds to the cross-ring cleavage of the sugar unit [33] and suggesting an aglycone-C-hexoside. The occurrence of another fragment ion at $m / z 269$ (apigenin aglycone) is caused by the loss of hexose moiety (-162 Da). Based on the above information, $\mathrm{C} 21$ was tentatively identified as apigenin-C-hexoside, known as Vitexin (Supplementary Figure S26). Vitexin was identified earlier in A. sinensis leaves [4]; its fragmentation pattern was reported in literature by [57]. Peak C39 was identified on positive ionization mode $(\mathrm{m} / \mathrm{z}$ $285.0748, \mathrm{C}_{16} \mathrm{H}_{13} \mathrm{O}_{5}{ }^{+}$), and exhibits similar fragmentation pattern of peak $\mathrm{C} 34$ with extra $\mathrm{CH}_{3}$ group (15 Da), which suggests that the compound is methyl apigenin, known as acacetin (Supplementary Figure S27). The fragmentation pattern of acacetin was previously identified by [56]. Furthermore, peak $\mathrm{C} 11\left(\mathrm{~m} / \mathrm{z} 593.1263, \mathrm{C}_{28} \mathrm{H}_{33} \mathrm{O}_{14}{ }^{+}\right)$on the positive mode showed a neutral loss of $146 \mathrm{Da}$ which is caused by the cleavage of deoxyhexose unit to give the fragment ion with $\mathrm{m} / \mathrm{z} 477$, followed by a loss of hexose unit (-162 Da) to produce the fragment ion with $\mathrm{m} / \mathrm{z} 285$, which suggest a disaccharide structure. The molecular weight of the compound after the elimination of two sugar units matches with that of acacetin, leading us to conclude that $\mathrm{C} 11$ is diglycosylated acacetin (acacetin-O-rutinoside) (Supplementary Figure S28) [56]. Likewise, peak $\mathrm{C} 41\left(\mathrm{~m} / \mathrm{z} 313.0726, \mathrm{C}_{17} \mathrm{H}_{13} \mathrm{O}_{6}{ }^{-}\right.$) upon fragmentation gave an ion at $\mathrm{m} / \mathrm{z} 283$; after the loss of two methyl groups, it was identified as velutin (Supplementary Figure S29). The fragmentation pattern of velutin was previously reported by [61], and the compound was recognized in A. sinensis stem barks and demonstrated potent anti-inflammatory activity [58]. The MS spectrum of peak $\mathrm{C} 24\left(\mathrm{~m} / \mathrm{z} 607.1660, \mathrm{C}_{28} \mathrm{H}_{31} \mathrm{O}_{15}{ }^{-}\right)$exhibited highly significant peak at $\mathrm{m} / \mathrm{z}$ 313 , which indicates the loss of $294 \mathrm{Da}$, which can be attributed to the cleavage of two pentose moieties. In contrast, the fragmentation ion at $\mathrm{m} / \mathrm{z} 313$ generated the product ions $\mathrm{m} / \mathrm{z} 298\left(-\mathrm{CH}_{3}\right)$ and $\mathrm{m} / z 283\left(-2 \mathrm{CH}_{3}\right)$, which is in agreement with the fragmentation of velutin. Such fragmentation suggests that $\mathrm{C} 24$ is a flavonoid glycoconjugate, whereas the aglycone is velutin. The compound is annotated as aquisiflavoside, which was isolated previously from $A$. sinensis leaves and was reported as potent nitric oxide inhibitor [62]. The fragmentation pattern of tentatively identified aquisiflavoside (Supplementary Figure S30) is introduced for the first time, as shown in Figure 5. Peak C40 (m/z 283.0617, $\mathrm{C}_{16} \mathrm{H}_{11} \mathrm{O}_{5}^{-}$), showing a fragment ion at $m / z 268\left[\mathrm{M}-\mathrm{H}-\mathrm{CH}_{3}\right]^{-}$, was assigned to genkwanin (Supplementary Figure S31), as previously reported in different Aquilaria species [63,64], while peak $\mathrm{C} 37\left(\mathrm{~m} / \mathrm{z} 299.0561, \mathrm{C}_{16} \mathrm{H}_{11} \mathrm{O}_{6}{ }^{-}\right)$expressed the presence of extra hydroxyl group to compound 40 , which suggests that C37 is Hydroxygenkwanin (Supplementary Figure S32). The fragmentation patterns of both peak $\mathrm{C} 40$ and $\mathrm{C} 37$ were previously reported in the $\mathrm{ms} / \mathrm{ms}$ analysis of $A$. sinensis leaves [38]. Peak $\mathrm{C} 26\left(\mathrm{~m} / z\right.$ 445.1136, $\left.\mathrm{C}_{21} \mathrm{H}_{17} \mathrm{O}_{11}{ }^{-}\right)$produced a fragment ion at $m / z 268$ [M-2H-176] caused by the loss of the glucuronide group, as reported by [65], and was nominated as baicalein-O-glucuronide (Supplementary Figure S33). Violanthin is a C-glycoside flavone that has been lately isolated from A. malaccensis leaves, and which has revealed antioxidant activity [66]. Violanthin was assigned to peak C44 (m/z 577.2710, $\left.\mathrm{C}_{27} \mathrm{H}_{29} \mathrm{O}_{14}{ }^{-}\right)$with the molecular weight of violanthin $(578.2 \mathrm{~g} / \mathrm{mol})$ as reported in the literature, and a fragment ion produced at $m / z 268$ (Supplementary Figure S34). 


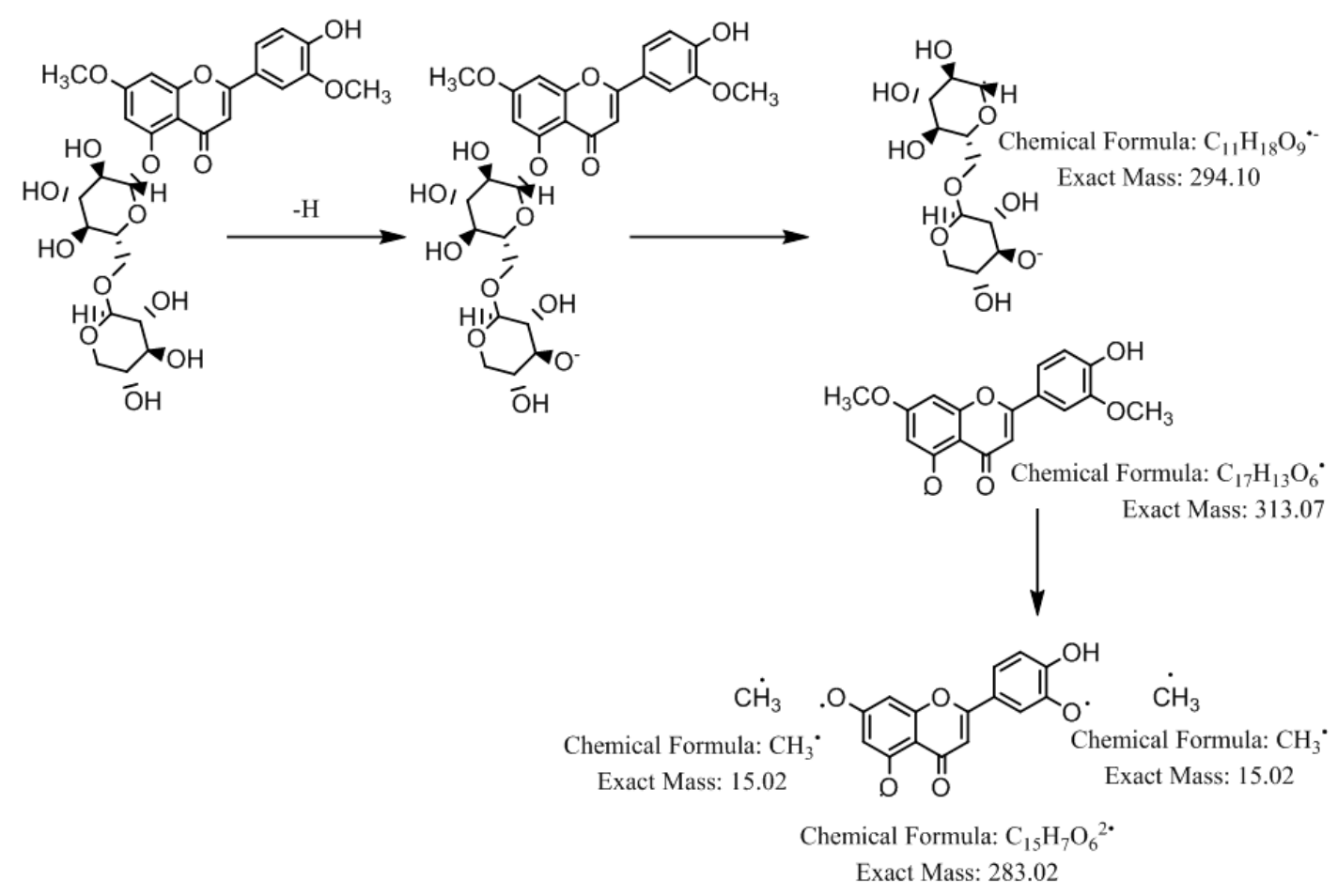

Figure 5. Fragmentation pattern of Aquisiflavoside on negative ion mode.

- Isoflavones

Two isoflavones were detected on the positive mode ionization. Peak C25 ( $\mathrm{m} / \mathrm{z} 447.1280$, $\mathrm{C}_{22} \mathrm{H}_{23} \mathrm{O}_{10}{ }^{+}$) was identified as sissotrin, which produced fragment ions at $\mathrm{m} / \mathrm{z} 285$ and $\mathrm{m} / \mathrm{z} 270$, caused by loss of the hexose moiety (162 Da), followed by the loss of the methyl group (15 Da) (Supplementary Figure S35), while peak $\mathrm{C} 45\left(\mathrm{~m} / z 269.0810, \mathrm{C}_{16} \mathrm{H}_{13} \mathrm{O}_{4}{ }^{+}\right)$was assigned to formononetin, and exhibited a fragment ion at $m / z 254$ after methyl group dissociation (Supplementary Figure S36). Sissotrin is identified in Aquilaria species for the first time. Meanwhile, formononetin was isolated earlier from $A$. sinensis stems [67]. The fragmentation patterns of sissotrin and formononetin were reported by $[68,69]$, respectively.

\subsubsection{Xanthones}

Xanthones-C-glycosides were observed in the sample. The MS/MS spectra of peak C4 ( $\mathrm{m} / z$ 421.0770, $\mathrm{C}_{19} \mathrm{H}_{17} \mathrm{O}_{11}{ }^{-}$) showed a fragment ion at $m / z 403$ which may be attributed to the loss of $\mathrm{H}_{2} \mathrm{O}$ molecule (18 Da). The fragment ions $m / z 331$ [M-H-90] $]^{-}$and $m / z 301$ [M-H-120] $]^{-}$suggest xanthone-C-glycosides compounds. C4 was tentatively identified as mangiferin or isomangiferin (Supplementary Figure S37). Mangiferin was previously identified in Aquilaria leaves [36,63,64]. Peak C9 (m/z 435.0979, $\left.\mathrm{C}_{20} \mathrm{H}_{19} \mathrm{O}_{11}{ }^{-}\right)$ produced a fragment ion at $\mathrm{m} / \mathrm{z} 417$ due to the loss of the $\mathrm{H}_{2} \mathrm{O}$ molecule, and was tentatively identified as homomangiferin (Supplementary Figure S38). The MS/MS spectra of C4 and C9 were previously reported in the LC-MS analysis of $A$. sinensis leaves [38].

\subsubsection{Sterols}

Two plant-derived sterols were detected in the sample on the positive ionization mode. The characteristic MS/MS spectra that have been obtained from free sterols occur as $\left[\mathrm{M}+\mathrm{H}-\mathrm{H}_{2} \mathrm{O}\right]^{+}[70]$.

Peaks C50 (m/z 415.3518, $\left.\mathrm{C}_{29} \mathrm{H}_{5} 1 \mathrm{O}^{+}\right)$and $\mathrm{C} 51\left(\mathrm{~m} / \mathrm{z} 413.3785, \mathrm{C}_{29} \mathrm{H}_{49} \mathrm{O}^{+}\right)$yielded significant fragmentation ions at $\mathrm{m} / \mathrm{z} 397$ and $\mathrm{m} / \mathrm{z} 395$ respectively, which was attributed to the loss of the $\mathrm{H}_{2} \mathrm{O}$ molecule $(18 \mathrm{Da})$. The detected phytosterols were identified as $\beta$-sitosterol (Supplementary Figure S39) and stigmasterol (Supplementary Figure S40). The fragmentation patterns of C50 and C51 
are reported in [71]. $\beta$-sitosterol was formerly isolated from $A$. sinensis stem barks and evaluated for its anti-inflammatory activity [58], and was also present in the GC-MS profile of the methanolic extract of A. sinensis leaves [32]. However, it was absent in the GC-MS analaysis of the methanolic extract of A. malaccensis leaves [32]. Stigmasterol was detected in A. malaccensis wood using GC-MS, and is also known for its potent anti-inflammatory activity [30].

\subsubsection{Terpenoids}

The complex organic compounds known as terpenoids consist of five carbon isoprene units, and are classified according to the number of isoprene units into monoterpenes, diterpenes, triterpenes, and sesquiterpenes [72]. Five terpenoids were identified in the extract on the positive ion mode.

Peak C8 (m/z 137.0596, $\left.\mathrm{C}_{10} \mathrm{H}_{17}{ }^{+}\right)$produced a major fragment ion at $\mathrm{m} / \mathrm{z} 122$ due to the loss of $\mathrm{CH}_{3}$ group, and was tentatively annotated as the monoterpene sabinene (Supplementary Figure S41). The fragmentation pattern of sabinene is presented in Figure 6. Phytol diterpene was assigned to peak $\mathrm{C} 36\left(\mathrm{~m} / \mathrm{z} 297.1127, \mathrm{C}_{20} \mathrm{H}_{41} \mathrm{O}^{+}\right)$, and yielded a fragment ion at $\mathrm{m} / \mathrm{z} 281$ (Supplementary Figure S42). Phytol has been identified in the GC-MS run of $A$. malaccensis ethanolic leaf extract, as in Table 2. Peaks C46 (m/z 223.1681, $\left.\mathrm{C}_{15} \mathrm{H}_{27} \mathrm{O}^{+}\right)$and $49\left(\mathrm{~m} / \mathrm{z} 427.3582, \mathrm{C}_{30} \mathrm{H}_{51} \mathrm{O}^{+}\right)$were tentatively recognized as the sesquiterpenes nerolidol (Supplementary Figure S43) and $\alpha$-amyrin (Supplementary Figure S44) according to the fragmentation patterns suggested by [71,73] respectively. The triterpenoid Lupeol was assigned to peak $\mathrm{C} 52\left(\mathrm{~m} / \mathrm{z} 427.3911, \mathrm{C}_{30} \mathrm{H}_{51} \mathrm{O}^{+}\right)$, which yielded a major fragment ion at $m / z 409$ due to the cleavage of $\mathrm{H}_{2} \mathrm{O}$ molecule ( $-18 \mathrm{Da}$ ) (Supplementary Figure S45) [71]. Lupeol was reported in the literature to exhibit anti-inflammatory and antiarthritic activities [74]. Although the aforementioned terpenoids have not been isolated from Aquilaria species to date, sabinene, phytol, and nerolidol were detected previously in the GC-MS profile of an A. malaccensis leaf extract [32].

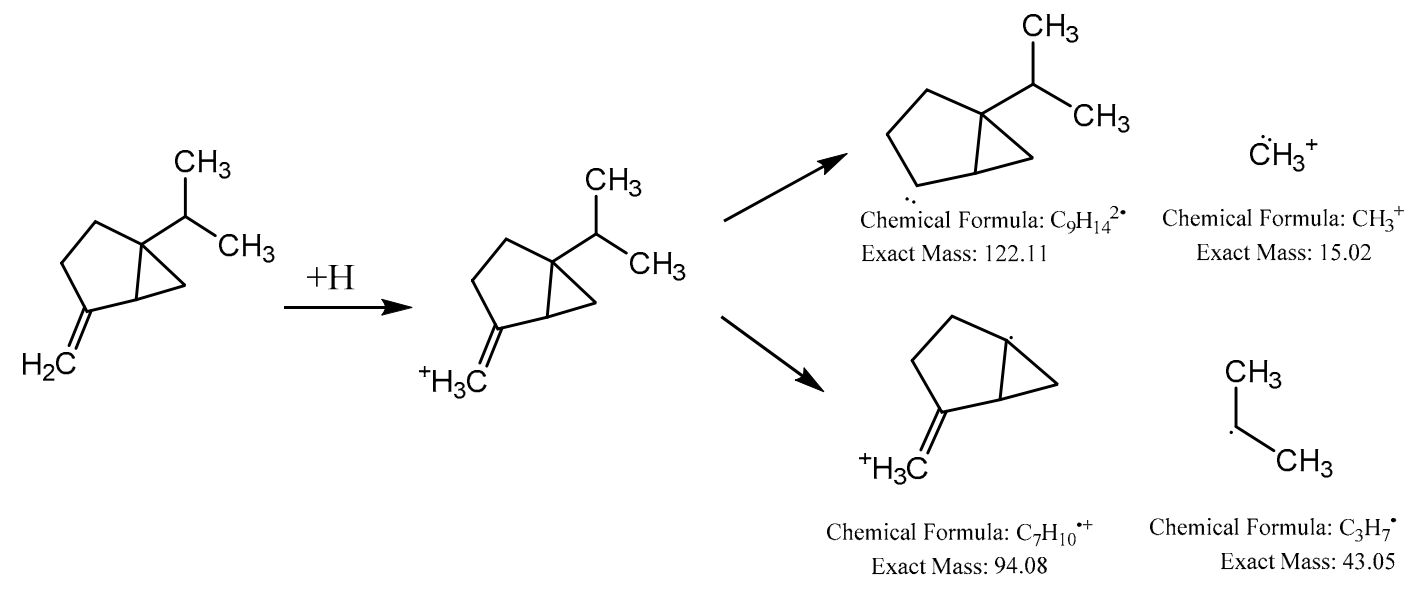

Figure 6. Fragmentation pattern of Sabinene on positive ion mode. 
Table 3. Metabolites identified in A. malaccensis leaf ethanolic extract via LC/Q-TOF-MS in negative (N) and positive (P) ionization modes.

\begin{tabular}{|c|c|c|c|c|c|c|c|c|c|}
\hline Peak & Mode & RT (min) & $\mathbf{M}^{+/-}$ & Formula & Error & Fragmentation Pattern & Identification & Class & Literature Data \\
\hline $\mathrm{C} 1$ & $\mathrm{~N}$ & 0.452 & 133.0152 & $\mathrm{C}_{4} \mathrm{H}_{5} \mathrm{O}_{5}^{-}$ & -2.2 & $115,89,71$ & Malic acid & Phenolic acid & [34], MoNA \\
\hline $\mathrm{C} 2$ & $\mathrm{~N}$ & 0.452 & 117.0182 & $\mathrm{C}_{4} \mathrm{H}_{5} \mathrm{O}_{4}^{-}$ & 2.9 & 99,73 & Succinic acid & Phenolic acid & [34], HMDB \\
\hline $\mathrm{C} 3$ & $\mathrm{~N}$ & 0.499 & 153.0199 & $\mathrm{C}_{7} \mathrm{H}_{5} \mathrm{O}_{4}^{-}$ & -0.7 & $109,91,81$ & Protocatechuic acid & Phenolic acid & [34], MoNA \\
\hline $\mathrm{C} 4$ & $\mathrm{~N}$ & 0.515 & 421.0770 & $\mathrm{C}_{19} \mathrm{H}_{17} \mathrm{O}_{11}^{-}$ & 1.2 & $403,331,301,259$ & Mangiferin/Isomangiferin & Xanthone & [38], MoNA \\
\hline $\mathrm{C} 5$ & $\mathrm{~N}$ & 0.659 & 163.0390 & $\mathrm{C}_{9} \mathrm{H}_{7} \mathrm{O}_{3}^{-}$ & 1.7 & 147,119 & Coumaric acid & Phenolic acid & [34], HMDB \\
\hline \multirow{2}{*}{$\mathrm{C} 6$} & $\mathrm{P}$ & 1.673 & 291.0896 & $\mathrm{C}_{15} \mathrm{H}_{15} \mathrm{O}_{6}{ }^{+}$ & 7.8 & $165,147,139,123$ & \multirow{2}{*}{ Catechin } & \multirow{2}{*}{ Flavanol } & [42], MoNA \\
\hline & $\mathrm{N}$ & 1.709 & 289.0739 & $\mathrm{C}_{15} \mathrm{H}_{13} \mathrm{O}_{6}^{-}$ & 1.1 & $271,245,179,151,137,109$ & & & [43], MoNA \\
\hline $\mathrm{C} 7$ & $\mathrm{~N}$ & 2.202 & 385.1896 & $\mathrm{C}_{17} \mathrm{H}_{21} \mathrm{O}_{10}^{-}$ & -0.6 & $223,205,179$ & Glucopyranosyl sinapate & Phenolic acid & [35] \\
\hline $\mathrm{C} 8$ & $\mathrm{P}$ & 2.408 & 137.0596 & $\mathrm{C}_{10} \mathrm{H}_{17}{ }^{+}$ & -0.1 & $122,94,81,77$ & Sabinene & Monoterpene & - \\
\hline C9 & $\mathrm{N}$ & 2.484 & 435.0979 & $\mathrm{C}_{20} \mathrm{H}_{19} \mathrm{O}_{11}^{-}$ & 0.7 & $417,345,315,272$ & Homomangiferin & Xanthone & [38] \\
\hline $\mathrm{C} 10$ & $\mathrm{~N}$ & 2.627 & 461.0711 & $\mathrm{C}_{21} \mathrm{H}_{17} \mathrm{O}_{12}^{-}$ & 0.8 & 285,175 & Kaempferol-O-Glucuronide & Flavonol & [48], MoNA \\
\hline $\mathrm{C} 11$ & $\mathrm{P}$ & 2.728 & 593.1263 & $\mathrm{C}_{28} \mathrm{H}_{33} \mathrm{O}_{14}{ }^{+}$ & 0.8 & 477,285 & Acacetin-O-rutinoside & Flavone & [56], NIST \\
\hline $\mathrm{C} 12$ & $\mathrm{~N}$ & 2.864 & 391.1029 & $\mathrm{C}_{19} \mathrm{H}_{19} \mathrm{O}_{9}^{-}$ & 0.4 & 245,151 & Iriflophenone-2-O- $\alpha$-L-rhamnopyranoside & Benzophenone & [38] \\
\hline $\mathrm{C} 13$ & $\mathrm{~N}$ & 3.067 & 245.0472 & $\mathrm{C}_{13} \mathrm{H}_{9} \mathrm{O}_{5}^{-}$ & 3.9 & 151,107 & Iriflophenone & Benzophenone & [38] \\
\hline $\mathrm{C} 14$ & $\mathrm{~N}$ & 3.362 & 549.1127 & - & 1.1 & 531,115 & Unknown & - & - \\
\hline $\mathrm{C} 15$ & $\mathrm{~N}$ & 3.424 & 463.0889 & $\mathrm{C}_{21} \mathrm{H}_{18} \mathrm{O}_{12}^{-}$ & 3.6 & 301,271 & Quercetin-O-hexoside & Flavonol & [47], HMDB \\
\hline $\mathrm{C} 16$ & $\mathrm{P}$ & 3.681 & 179.1070 & $\mathrm{C}_{9} \mathrm{H}_{7} \mathrm{O}_{4}^{+}$ & 0.5 & $161,146,133$ & Dihydroxycoumarin (Esculetin) & Coumarin & [75], HMDB \\
\hline $\mathrm{C} 17$ & $\mathrm{~N}$ & 3.807 & 447.0946 & $\mathrm{C}_{21} \mathrm{H}_{19} \mathrm{O}_{11}^{-}$ & 1.6 & 285 & Luteolin-O-hexoside & Flavone & [56], HMDB \\
\hline $\mathrm{C} 18$ & $\mathrm{~N}$ & 4.242 & 477.1034 & $\mathrm{C}_{22} \mathrm{H}_{21} \mathrm{O}_{12}^{-}$ & -0.9 & 315,271 & Isorhamnetin-O-hexoside & Flavonol & [51], MoNA \\
\hline C19 & $\mathrm{N}$ & 4.282 & 507.1551 & $\mathrm{C}_{23} \mathrm{H}_{23} \mathrm{O}_{13}{ }^{-}$ & -0.5 & 344 & Syringetin-O-hexoside & Flavonol & [52], MoNA \\
\hline $\mathrm{C} 20$ & $\mathrm{~N}$ & 4.512 & 317.0315 & $\mathrm{C}_{15} \mathrm{H}_{9} \mathrm{O}_{8}^{-}$ & 0.7 & 179,151 & Myricetin & Flavonol & [53], HMDB \\
\hline $\mathrm{C} 21$ & $\mathrm{~N}$ & 4.550 & 431.0995 & $\mathrm{C}_{21} \mathrm{H}_{19} \mathrm{O}_{10}{ }^{-}$ & -0.7 & 311,269 & Apigenin-C-hexoside (Vitexin) & Flavone & [57], MoNA \\
\hline $\mathrm{C} 22$ & $\mathrm{P}$ & 4.664 & 579.1703 & $\mathrm{C}_{27} \mathrm{H}_{31} \mathrm{O}_{14}^{+}$ & -1.7 & 285 & Kaempferol-O-dirhamnoside & Flavonol & [50] \\
\hline $\mathrm{C} 23$ & $\begin{array}{l}\mathrm{P} \\
\mathrm{N}\end{array}$ & $\begin{array}{l}4.820 \\
4.833\end{array}$ & $\begin{array}{l}435.1296 \\
433.1136\end{array}$ & $\begin{array}{l}\mathrm{C}_{21} \mathrm{H}_{23} \mathrm{O}_{10}^{+} \\
\mathrm{C}_{21} \mathrm{H}_{21} \mathrm{O}_{10}^{-}\end{array}$ & $\begin{array}{c}-1.7 \\
0.3\end{array}$ & $\begin{array}{c}247 \\
245,151\end{array}$ & $\begin{array}{c}\text { Iriflophenone, } \\
\text { [2-(2-O-actyA-L-Rhamnopyranosyl) oxy] }\end{array}$ & Benzophenone & - \\
\hline $\mathrm{C} 24$ & $\mathrm{~N}$ & 4.954 & 607.1660 & $\mathrm{C}_{28} \mathrm{H}_{31} \mathrm{O}_{15}{ }^{-}$ & 3.4 & 313,298 & Aquisiflavoside & Flavone & - \\
\hline $\mathrm{C} 25$ & $\mathrm{P}$ & 5.022 & 447.1280 & $\mathrm{C}_{22} \mathrm{H}_{23} \mathrm{O}_{10}{ }^{+}$ & 0.6 & 285,270 & Sissotrin & Isoflavone & [68], NIST \\
\hline $\mathrm{C} 26$ & $\mathrm{~N}$ & 5.097 & 445.1136 & $\mathrm{C}_{21} \mathrm{H}_{17} \mathrm{O}_{11}^{-}$ & 0.2 & 268 & Baicalein-O-glucuronide & Flavone & [65], MoNA \\
\hline
\end{tabular}


Table 3. Cont.

\begin{tabular}{|c|c|c|c|c|c|c|c|c|c|}
\hline Peak & Mode & RT (min) & $\mathbf{M}^{+/-}$ & Formula & Error & Fragmentation Pattern & Identification & Class & Literature Data \\
\hline $\mathrm{C} 27$ & $\mathrm{~N}$ & 5.214 & 287.0579 & $\mathrm{C}_{15} \mathrm{H}_{11} \mathrm{O}_{6}^{-}$ & -0.1 & $151,135,107$ & tetrahydroxyflavanone & Flavanone & [54] \\
\hline $\mathrm{C} 28$ & $\mathrm{~N}$ & 5.565 & 285.0409 & $\mathrm{C}_{15} \mathrm{H}_{9} \mathrm{O}_{6}^{-}$ & 1.1 & 133 & Luteolin & Flavone & [57], HMDB \\
\hline $\mathrm{C} 29$ & $\mathrm{~N}$ & 5.728 & 301.0360 & $\mathrm{C}_{15} \mathrm{H}_{9} \mathrm{O}_{7}^{-}$ & -0.9 & $273,179,151$ & Quercetin & Flavonol & [47], HMDB \\
\hline $\mathrm{C} 30$ & $\begin{array}{l}\mathrm{N} \\
\mathrm{P}\end{array}$ & $\begin{array}{l}5.895 \\
5.939\end{array}$ & $\begin{array}{l}553.1350 \\
555.1508\end{array}$ & $\begin{array}{l}\mathrm{C}_{25} \mathrm{H}_{29} \mathrm{O}_{14}^{-} \\
\mathrm{C}_{25} \mathrm{H}_{31} \mathrm{O}_{14}{ }^{+}\end{array}$ & $\begin{array}{c}-0.9 \\
0.7\end{array}$ & $\begin{array}{c}391,245,151 \\
291,247,121,83\end{array}$ & Aquilarisinin & Benzophenone & - \\
\hline $\mathrm{C} 31$ & $\mathrm{~N}$ & 6.094 & 417.1582 & $\mathrm{C}_{22} \mathrm{H}_{25} \mathrm{O}_{8}^{-}$ & -2.6 & $402,181,166,151$ & Syringaresinol & Lignan & [76], MoNA \\
\hline C32 & $\mathrm{N}$ & 6.167 & 623.1359 & $\mathrm{C}_{28} \mathrm{H}_{31} \mathrm{O}_{16}{ }^{-}$ & 3 & 315 & Isorhamnetin-O-rutinoside (narcissoside) & Flavonol & [51], MoNA \\
\hline $\mathrm{C} 33$ & $\mathrm{~N}$ & 6.254 & 593.1518 & $\mathrm{C}_{27} \mathrm{H}_{29} \mathrm{O}_{15}^{-}$ & 0.8 & 299,285 & Kaempferol-O-neohesperidoside & Flavonol & [49], MoNA \\
\hline $\mathrm{C} 34$ & $\begin{array}{l}\mathrm{N} \\
\mathrm{P}\end{array}$ & $\begin{array}{l}6.499 \\
6.638 \\
\end{array}$ & $\begin{array}{l}269.0473 \\
271.0601 \\
\end{array}$ & $\begin{array}{l}\mathrm{C}_{15} \mathrm{H}_{9} \mathrm{O}_{5}^{-} \\
\mathrm{C}_{15} \mathrm{H}_{11} \mathrm{O}_{5}{ }^{+}\end{array}$ & $\begin{array}{l}0.1 \\
3.8 \\
\end{array}$ & $\begin{array}{c}151,149,117 \\
229,153\end{array}$ & Apigenin & Flavone & $\begin{array}{l}\text { [51], MoNA } \\
\text { [60], MoNA }\end{array}$ \\
\hline C35 & $\mathrm{N}$ & 6.931 & 301.0588 & $\mathrm{C}_{16} \mathrm{H}_{13} \mathrm{O}_{6}^{-}$ & 0.2 & 286,255 & Hesperetin & Flavanone & {$[55,56]$, MoNA } \\
\hline C36 & $\mathrm{P}$ & 8.019 & 297.1127 & $\mathrm{C}_{20} \mathrm{H}_{41} \mathrm{O}^{+}$ & 1.9 & $281,265,248$ & Phytol & Diterpene & MoNA \\
\hline C37 & $\mathrm{N}$ & 8.352 & 299.0561 & $\mathrm{C}_{16} \mathrm{H}_{11} \mathrm{O}_{6}^{-}$ & -4.3 & 284,256 & Hydroxygenkwanin & Flavone & [38], HMDB \\
\hline $\mathrm{C} 38$ & $\mathrm{~N}$ & 9.302 & 285.0774 & $\mathrm{C}_{16} \mathrm{H}_{13} \mathrm{O}_{5}^{-}$ & 4.6 & $165,119,93$ & Sakuranetin & Flavanone & [57], HMDB \\
\hline C39 & $\mathrm{P}$ & 9.310 & 285.0748 & $\mathrm{C}_{16} \mathrm{H}_{13} \mathrm{O}_{5}^{+}$ & 1.1 & $270,242,176,124$ & Acacetin & Flavone & [56] MoNA \\
\hline $\mathrm{C} 40$ & $\mathrm{~N}$ & 9.445 & 283.0617 & $\mathrm{C}_{16} \mathrm{H}_{11} \mathrm{O}_{5}^{-}$ & 2.5 & 268 & Genkwanin & Flavone & [38], MoNA \\
\hline C41 & $\mathrm{N}$ & 9.683 & 313.0726 & $\mathrm{C}_{17} \mathrm{H}_{13} \mathrm{O}_{6}{ }^{-}$ & 1.8 & $298,283,270,255$ & Velutin & Flavone & [61], MoNA \\
\hline $\mathrm{C} 42$ & $\mathrm{P}$ & 9.891 & 307.2488 & - & 2.3 & $289,271,220$ & Unknown & - & - \\
\hline $\mathrm{C} 43$ & $\mathrm{P}$ & 10.856 & 329.1022 & - & -0.4 & 313,285 & Unknown & - & - \\
\hline $\mathrm{C} 44$ & $\mathrm{~N}$ & 11.757 & 577.2710 & $\mathrm{C}_{27} \mathrm{H}_{29} \mathrm{O}_{14}^{-}$ & -0.3 & 268 & Violanthin & Flavone & MoNA \\
\hline $\mathrm{C} 45$ & $\mathrm{P}$ & 11.878 & 269.0810 & $\mathrm{C}_{16} \mathrm{H}_{13} \mathrm{O}_{4}{ }^{+}$ & 1.3 & 254,197 & Formononetin & Isoflavone & [69] \\
\hline $\mathrm{C} 46$ & $\mathrm{P}$ & 12.302 & 223.1681 & $\mathrm{C}_{15} \mathrm{H}_{27} \mathrm{O}^{+}$ & -0.6 & $207,191,177,149$ & Nerolidol & Sesquiterpenes & [73], MoNA \\
\hline $\mathrm{C} 47$ & $\mathrm{~N}$ & 16.856 & 279.2330 & $\mathrm{C}_{18} \mathrm{H}_{31} \mathrm{O}_{2}^{-}$ & 4 & 261,234 & Linoleic acid & Fatty acid & MoNA \\
\hline $\mathrm{C} 48$ & $\mathrm{~N}$ & 17.976 & 255.2334 & $\mathrm{C}_{16} \mathrm{H}_{31} \mathrm{O}_{2}^{-}$ & -0.9 & 237 & Hexadecanoic acid & Fatty acid & MoNA \\
\hline $\mathrm{C} 49$ & $\mathrm{P}$ & 19.775 & 427.3582 & $\mathrm{C}_{30} \mathrm{H}_{51} \mathrm{O}^{+}$ & -3 & $409,367,217,191$ & $\alpha$-amyrin & Sesquiterpenes & [71] \\
\hline $\mathrm{C} 50$ & $\mathrm{P}$ & 20.870 & 415.3518 & $\mathrm{C}_{29} \mathrm{H}_{51} \mathrm{O}^{+}$ & 1 & $397,189,161,119$ & $\beta$-sitosterol & Sterols & [71], HMDB \\
\hline C51 & $\mathrm{P}$ & 21.572 & 413.3785 & $\mathrm{C}_{29} \mathrm{H}_{49} \mathrm{O}^{+}$ & -1.7 & $395,255,159$ & Stigmasterol & Sterols & [71], HMDB \\
\hline $\mathrm{C} 52$ & $\mathrm{P}$ & 22.407 & 427.3911 & $\mathrm{C}_{30} \mathrm{H}_{51} \mathrm{O}^{+}$ & -1.6 & 409,185 & Lupeol & Triterpenoid & [71], NIST \\
\hline $\mathrm{C} 53$ & $\mathrm{P}$ & 23.782 & 431.3790 & $\mathrm{C}_{29} \mathrm{H}_{51} \mathrm{O}_{2}{ }^{+}$ & 0.7 & 165 & $\alpha$-Tocopherol & Tocopherols & [77], NIST \\
\hline
\end{tabular}

MoNA: MassBank of North America, NIST: National Institute of Standards and Technology, HMDB: Human Metabolome Database. 


\subsubsection{Coumarins}

Peak $\mathrm{C} 16\left(\mathrm{~m} / z\right.$ 179.1070, $\left.\mathrm{C}_{9} \mathrm{H}_{7} \mathrm{O}_{4}{ }^{+}\right)$initially produced the ion at $\mathrm{m} / \mathrm{z} 161$ due loss of $\mathrm{H}_{2} \mathrm{O}$ molecule $(-18 \mathrm{Da})$ followed by a fragment ion at $\mathrm{m} / \mathrm{z} 133$ caused by the dissociation of another $\mathrm{H}_{2} \mathrm{O}$ and $\mathrm{CO}$ molecules. The presence of the fragment ion at $\mathrm{m} / \mathrm{z} 146$, which is the similar molecular weight of coumarin $(146 \mathrm{~g} / \mathrm{mol})$ in the literature, suggests that the compound is a coumarin derivative. Accordingly, it can be anticipated that the compound is dihydroxycoumarin, known as esculetin [75] (Supplementary Figure S46).

\subsubsection{Lignans}

The MS/MS spectra of peak $\mathrm{C} 31\left(\mathrm{~m} / \mathrm{z} 417.1753, \mathrm{C}_{22} \mathrm{H}_{25} \mathrm{O}_{8}{ }^{-}\right)$showed fragmentation ions at $\mathrm{m} / \mathrm{z} 402$ and $m / z 387$ due to the successive loss of two methyl groups. A major fragment ion also occurred at $m / z 181$, representing the syringyl moiety, which subsequently lost two $\mathrm{CH}_{3}$ molecules, thereby forming a guaiacyl moiety at $m / z$ 151. The demonstrated fragmentation pattern matches with the fragmentation pattern of syringaresinol [76]. Hence, C31 is possibly syringaresinol (Supplementary Figure S47). The lignan syringaresinol has been determined in A. sinensis stem barks, and has been shown to demonstrate moderate anti-inflammatory activity [58].

\subsubsection{Fatty Acids}

Two fatty acids, namely, linoleic and hexadecanoic fatty acids, were detected in the present sample. Linoleic acid was assigned to peak $\mathrm{C} 47\left(\mathrm{~m} / \mathrm{z} 279.2330, \mathrm{C}_{18} \mathrm{H}_{31} \mathrm{O}_{2}{ }^{-}\right)$(Supplementary Figure S48), while Hexadecanoic acid was allocated to peak C48 (m/z 255.2334, $\mathrm{C}_{16} \mathrm{H}_{31} \mathrm{O}_{2}^{-}$) (Supplementary Figure S49). Both compounds yielded major fragment ions due to the breakdown of $\mathrm{H}_{2} \mathrm{O}$ molecules at $m / z 261$ and $m / z 237$ respectively. Both linoleic acid and hexadecanoic acid appeared in the GC-MS analysis of A. malaccensis leaves [32]. Hexadecanoic acid was also recognized in the GC-MS analysis of A. malaccensis leaves in the present study, as shown in Table 2.

\subsubsection{Tocopherols}

Peak C53 (m/z 431.3790, $\left.\mathrm{C}_{29} \mathrm{H}_{51} \mathrm{O}_{2}{ }^{+}\right)$was designated to $\alpha$-Tocopherol with a major fragment ion at $\mathrm{m} / \mathrm{z} 165$, caused by the cleavage of the tocopherol phytyl tail (Supplementary Figure S50), which is consistent with its fragmentation pattern presented by [77]. $\alpha$-Tocopherol, which has been previously identified in A. sinensis stem bark, has potential as an anti-inflammatory agent [58].

\subsection{The Antilipoxygenase Assay}

The anti-inflammatory potential of the A. malaccensis ethanolic extract was evaluated using the inhibition percentage of lipoxygenase enzyme in correlation to its $\mathrm{IC}_{50}$ value. The inhibition of lipoxygenase activity was demonstrated in a dose-dependent manner, whereas the maximum lipoxygenase inhibition occurred at a dose of $200 \mu \mathrm{g} / \mathrm{mL}(82.61 \% \pm 1.44 \%)$. Data were exported to MS Excel 2010 and the $\mathrm{IC}_{50}$ was determined. The extract was able to inhibit the lipoxygenase enzyme (LOX) with an $\mathrm{IC}_{50}$ of $71.6 \pm 5.44 \mu \mathrm{g} / \mathrm{mL}$ (Figure 7). The lipoxygenase enzyme converts the Arachidonic acid in the body cells to hydro peroxy eicosa tetraenoic acids (HPETEs), which are then reduced to leukotrienes that are considered to be among the most powerful inflammatory mediators $[78,79]$. Lipoxygenase enzyme is associated with several inflammatory disorders such as asthma, cancer, atherosclerosis, obesity, diabetes, and neurodegenerative diseases [78,79]. Thus, the antilipoxygenase activity of the extract can be exploited to combat a range of inflammation-related diseases. In a previous study, 160 Malaysian plant extracts were screened for lipoxygenase inhibiting effects at $100 \mu \mathrm{g} / \mathrm{mL}$; those with more than $70 \%$ inhibition were classified as highly active against lipoxygenase, those showing $41-70 \%$ inhibition as having moderate activity, and those with $0-40 \%$ as having low activity [80]. Accordingly, A. malaccensis leaf extract activity, with $65.56 \% \pm 2.75 \%$ inhibition of lipoxygenase at a dose of $100 \mu \mathrm{g} / \mathrm{mL}$, suggests that the extract exhibits potential moderate antilipoxygenase activity in a 
concentration-dependent manner. To best of our knowledge, no previous studies have been performed on the antilipoxygenase inhibitory potential of $A$. malaccensis extract.

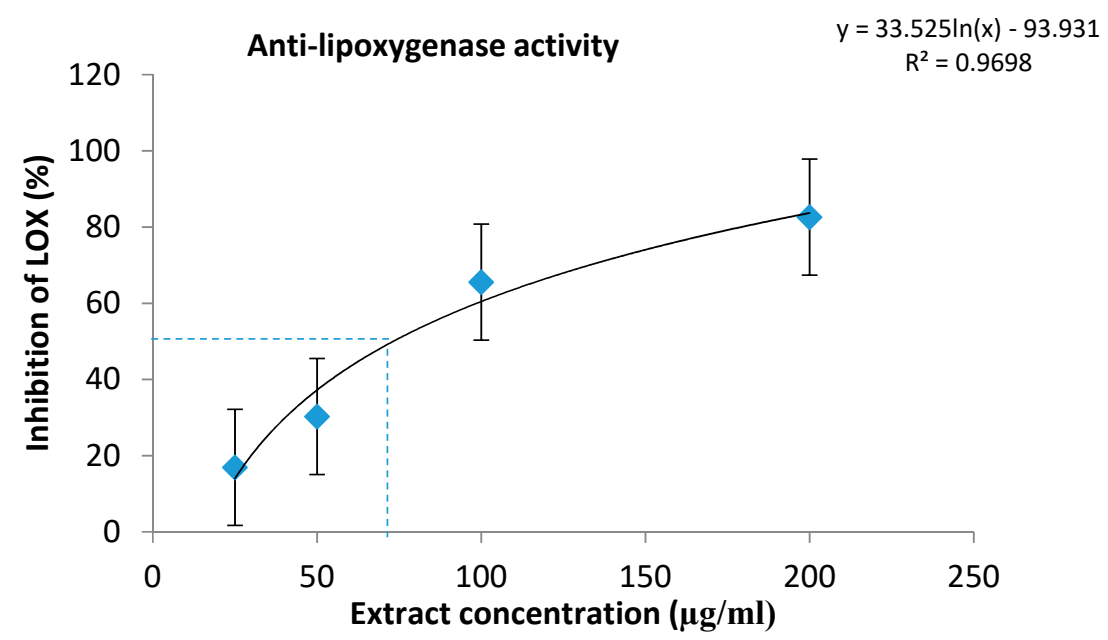

Figure 7. Antilipoxygenase (anti-LOX) activity of $A$. malaccensis leaf extract $\left(\mathrm{IC}_{50}: 71.6 \pm 5.44 \mu \mathrm{g} / \mathrm{mL}\right.$ ). LOX inhibition of the positive control (NDGA) at $100 \mu \mathrm{g} / \mathrm{mL}$ was $98.21 \% \pm 1.26 \%$. IC 50 of NDGA: $2.05 \pm 0.46 \mu \mathrm{g} / \mathrm{mL}$.

Based on the research results of phytochemical screening, GC-MS, and LC/Q-TOF-MS, the ethanolic extract of $A$. malaccensis leaf comprises diverse phytochemicals. The anti-inflammatory activity exhibited by the extract can be attributed to several bioactive constituents detected which are expected to inhibit pro-inflammatory mediators and enzymes such as lipoxygenase enzyme. As discussed, compounds such as iriflophenone (C13), catechin (C6), sakuranetin (C38), luteolin (C28), velutin (C41), aquisiflavoside (C24), $\beta$-sitosterol (C50), stigmasterol (C51), lupeol (C52), phytol, hexadecanoic acid, syringarsinol (C31), and $\alpha$-tocopherol (C53) have been previously shown to exhibit anti-inflammatory activity through varied mechanisms. However, no scientific report exists on the identified compounds as possible specific inhibitors of lipoxygenase enzyme.

\subsection{Toxicity Screening Assay}

A WST-1 assay was used to evaluate the toxicity of A. malaccensis leaf ethanolic extract on oral epithelial cells (OECs). WST-1 (4-[3-(4iodophenyl)-2-(4-nitrophenyl)-2H-5-tetrazolio]-1,3-benzene disulfonate) is a colorimetric assay that is commonly used to evaluate the toxicity of substances on mammalian cells through a reaction with the mitochondrial succinate-tetrazolium reductase forming the formazan dye in viable cells [81]. The assay is a rapid, single step assay, whereas WST-1 reagent forms soluble formazan in contrast to the MTT assay which forms insoluble formazan crystals [81]. The OECs are noncancerous cell lines derived from human oral squamous cells. The cells were selected for the present assay to represent normal cells that may be exposed to external pathogens which can benefit from anti-inflammatory therapeutic agents. Based on this preliminary finding, the cells viability $\%$ obtained from WST- 1 assay falls between $92.55 \% \pm 1.26 \%$ at a dose of $10 \mu \mathrm{g} / \mathrm{mL}$ to $76.06 \% \pm 1.16 \%$ at a dose of $100 \mu \mathrm{g} / \mathrm{mL}$. The reduction of cell viability in the preliminary screening could suggest the toxicity effects of the leaf extract. The concentration of the extract $(100 \mu \mathrm{g} / \mathrm{mL})$ that is able to exert moderate inhibition of lipoxygenase level causes a reduction in cell viability by $24 \%$. The implication of this finding suggests that although the extract has potential anti-inflammatory activity, its use should be cautioned, as it has shown some toxicity effects. Further research is warranted to investigate the potential toxicity of the leaf extract. 


\section{Conclusions}

Based on the present research, LC/Q-TOF-MS analysis successfully identified previously-isolated and newly-identified compounds in A. malaccensis leaves from a healthy noninoculated tree, comprising phenolic acids, benzophenones, flavonoids, xanthones, sterols, terpenoids, coumarins, lignans, fatty acids, and tocopherols. A number of compounds were identified for the first time in A. malaccensis leaves, including quercetin, quercetin-O-hexoside, kaempferol- $O$-dirhamnoside, isorhamnetin- $O$-hexoside, syringetin-O-hexoside, Myricetin, tetrahydroxyflavanone, hesperetin, sissotrin, and lupeol. The present work is the first to report on the antilipoxygenase activity of $A$. malaccensis leaves from a healthy noninoculated tree, and to investigate its toxicity on oral mucosal cells. The results from the biological assays suggest that the A. malaccensis leaf extract exhibits moderate antilipoxygenase activity and shows some toxicity risks regarding OEC. Future studies should be directed toward the bio-guided isolation and purification of compounds, as well as the plant mechanistic anti-inflammatory role to ensure its safety for human consumption.

Supplementary Materials: The following are available online at http://www.mdpi.com/2227-9717/8/2/202/s1, Supplementary Figures S1-S50.

Author Contributions: Conceived, designed and performed the experiments, analyzed data and wrote the paper, M.A.E.; supervision, funding acquisition, paper review and editing, Y.Z.H.-Y.H.; LC-MS method validation, paper review and editing, D.M.E.-K.; co-supervision, paper review and editing, S.S.S.A.-A.; co-supervision, H.M.S., M.L.M.I. and N.M.A.W. All authors have read and agreed to the published version of the manuscript.

Acknowledgments: The Fundamental Research Grant Scheme (FRGS/1/2019/WAB11/UIAM/02/4) awarded by the Ministry of Education, Malaysia, in support of this research is highly acknowledged.

Conflicts of Interest: The authors declare no conflict of interest.

\section{References}

1. Lee, S.Y.; Mohamed, R. The Origin and Domestication of Aquilaria, an Important Agarwood-Producing Genus. In Agarwood, 1st ed.; Mohamed, R., Ed.; Springer: Singapore, 2016; pp. 1-20.

2. Hashim, Y.Z.H.-Y.; Kerr, P.G.; Abbas, P.; Salleh, H.M. Aquilaria Spp. (Agarwood) as Source of Health Beneficial Compounds: A Review of Traditional Use, Phytochemistry and Pharmacology. J. Ethnopharmacol. 2016, 189, 331-360. [CrossRef]

3. Hendra, H.; Moeljopawiro, S.; Nuringtyas, T.R. Antioxidant and Antibacterial Activities of Agarwood (Aquilaria malaccensis Lamk.) Leaves. AIP Conf. Proc. 2016, 1755.

4. Adam, A.Z.; Lee, S.Y.; Mohamed, R. Pharmacological Properties of Agarwood Tea Derived from Aquilaria (Thymelaeaceae) Leaves: An Emerging Contemporary Herbal Drink. J. Herb. Med. 2017, 10, 37-44. [CrossRef]

5. Valentine, N.E.; Apridamayanti, P.; Sari, R. Fici Value of Aquilaria malaccensis Leaves Extract and Amoxicillin against Proteus Mirabilis and Pseudomonas Aeruginosa. Kartika J. Ilm. Farm. 2019, 6, 86-90. [CrossRef]

6. Nadilah, W.A.; Ali, A.M.; Nur, W.A.; Hasima, N. Evaluation of DPPH Free Radical Scavenging, $\alpha$-Glucosidase Inhibitory, and Antimicrobial Activities of Aquilaria malaccensis Leaf Extracts. J. Agrobiotech. 2019, 10, 36-45.

7. Dash, M.; Patra, J.K.; Panda, P.P. Phytochemical and antimicrobial screening of extracts of Aquilaria agallocha Roxb. Afr. J. Biotechnol. 2008, 7, 3531-3534.

8. Batubara, R.; Hanum, T.I.; Pulungan, W. Phytochemical and Antioxidant Activity of Gaharu Leaf Tea (Aquilaria malaccensis Lamk) as Raw Material of Tea from Middle Tapanuli Regency, North Sumatera Province. IOP Conf. Ser. Earth Environ. Sci. 2019, 260, 012101.

9. Rahman, H.; Eswaraiah, M.C.; Dutta, A.M. Anti-arthritic activity of leaves and oil of Aquilaria agallocha. Saudi J. Life Sci. 2016, 1, 34-43.

10. Alam, J.; Mujahid, M.; Jahan, Y.; Bagga, P.; Rahman, M.A. Hepatoprotective Potential of Ethanolic Extract of Aquilaria agallocha Leaves against Paracetamol Induced Hepatotoxicity in SD Rats. J. Tradit. Complement. Med. 2017, 7, 9-13. [CrossRef]

11. Dyary, H.O.; Arifah, A.K.; Sharma, R.S.; Rasedee, A.; Mohd-Aspollah, M.S.; Zakaria, Z.A.; Zuraini, A.; Somchit, M.N. Antitrypanosomal screening and cytotoxic effects of selected medicinal plants. Trop. Biomed. 2014, 31, 89-96. 
12. Eissa, M.; Hashim, Y.Z.H.Y.; Zainurin, N.A.A. Aquilaria malaccensis Leaf as an Alternative Source of Anti-Inflammatory Compounds. Int. J. Adv. Sci. Eng. Inf. Technol. 2018, 8, 1625-1632. [CrossRef]

13. Ismail, F.; Wahab, A.Y.A.; Isa, M.L.M.; Muhammad, H.; Ismail, R.A.S.R.; Razak, R.N.H.A. The Effects of Aquilaria malaccensis Leaves Aqueous Extract on Sperm of Sprague Dawley Rats towards Early Embryogenesis. Int. Med. J. Malays. 2019, 18, 59-68.

14. Musa, N.H.C.; Zain, H.H.M.; Ibrahim, H.; Jamil, N.N.M. Evaluation of Acute and Sub-Acute Oral Toxicity Effect of Aquilaria malaccensis Leaves Aqueous Extract in Male ICR Mice. Nat. Prod. Sci. 2019, 25, 157-164. [CrossRef]

15. Hegde, K.; Shree, D.P.M.; Sajjan, P.C. Evaluation of Immunomodulatory Potentials of the Leaves of Aquilaria malaccensis. Res. J. Pharmacol. Pharmacodyn. 2019, 11, 32-36. [CrossRef]

16. Afiffudden, S.K.N.; Alwi, H.; Hamid, K.H.K. Determination of 4'-Hydroxyacetanilide in Leaves Extract of Aquilaria malaccencis by High Pressure Liquid Chromatograph. Procedia-Soc. Behav. Sci. 2015, 195, 2726-2733. [CrossRef]

17. Pesic, M.; Greten, F.R. Inflammation and Cancer: Tissue Regeneration Gone Awry. Curr. Opin. Cell Biol. 2016, 43, 55-61. [CrossRef]

18. Rao, U.M.; Ahmad, B.A.; Mohd, K.S. In Vitro Nitric Oxide Scavenging and AntiInflammatory Activities of Different Solvent Extracts of Various Parts of Musa paradisiaca. Malays. J. Anal. Sci. 2016, 20, 1191-1202. [CrossRef]

19. Sultana, N.; Saify, Z.S. Naturally Occurring and Synthetic Agents as Potential Anti-Inflammatory and Immunomodulants. Anti-Inflamm. Anti-Allergy Agents Med. Chem. 2012, 11, 3-19. [CrossRef]

20. Bijekar, S. Phytochemical profile of Codiaeum variegatum (L.). Int. J. Pharmacol. Pharm. Sci. 2015, 2, $22-31$.

21. Hashim, Y.Z.H.-Y.; Ismail, N.I.; Abbas, P. Analysis Of Chemical Compounds of Agarwood Oil From Different Species By Gas Chromatography Mass Spectrometry (Gcms). IIUM Eng. J. 2014, 15, 55-60. [CrossRef]

22. Azhar-Ul-Haq, A.-U.-H.; Malik, A.; Anis, I.; Khan, S.B.; Ahmed, E.; Ahmed, Z.; Nawaz, S.A.; Choudhary, M.I. Enzymes Inhibiting Lignans from Vitex negundo. Chem. Pharm. Bull. 2005, 52, 1269-1272. [CrossRef] [PubMed]

23. Sharma, A.; Marceau, C.; Hamaguchi, R.; Burridge, P.W.; Rajarajan, K.; Churko, J.M.; Wu, H.; Sallam, K.I.; Matsa, E.; Sturzu, A.C.; et al. Human Induced Pluripotent Stem Cell-Derived Cardiomyocytes as an In Vitro Model for Coxsackievirus B3-Induced Myocarditis and Antiviral Drug Screening Platform. Circ. Res. 2014, 115, 556-566. [CrossRef] [PubMed]

24. Alaufi, O.M.; Noorwali, A.; Zahran, F.; Al-Abd, A.M.; Al-Attas, S. Cytotoxicity of Thymoquinone Alone or in Combination with Cisplatin (CDDP) against Oral Squamous Cell Carcinoma in Vitro. Sci. Rep. 2017, 7, 1-12. [CrossRef] [PubMed]

25. Batubara, R.; Hanum, T.I.; Surjanto. Phytochemical and Tannin Content in Two Species of Agarwood Leaves from Mandailing Natal Regency North Sumatera Province. In AIP Conference Proceedings; AIP Publishing: New York, NY, USA, 2018; Volume 2049, p. 030009.

26. Maharani, R.; Fernandes, A.; Turjaman, M.; Lukmandaru, G.; Kuspradini, H. The characterization of phytochemical and gc-ms analysis on borneo agarwood (Aquilaria malaccensis lamk) leaves and its utilization as an anti- browning in apple juice. Int. J. Pharmacogn. Phytochem. Res. 2016, 8, 1576-1582.

27. Khalil, A.S.; Rahim, A.A.; Taha, K.K.; Abdallah, K.B. Characterization of Methanolic Extracts of Agarwood Leaves. J. Appl. Ind. Sci. 2013, 1, 78-88.

28. Aparna, V.; Dileep, K.V.; Mandal, P.K.; Karthe, P.; Sadasivan, C.; Haridas, M. Anti-Inflammatory Property of n-Hexadecanoic Acid: Structural Evidence and Kinetic Assessment. Chem. Biol. Drug Des. 2012, 80, 434-439. [CrossRef]

29. Prakasia, P.; Nair, A. Chemical fingerprint of essential oil components from fresh leaves of Glycosmis pentaphylla (Retz.) Correa. Pharma. Innov. J. 2015, 3, 50-56.

30. Jong, P.L.; Tsan, P.; Mohamed, R. Gas Chromatography-Mass Spectrometry Analysis of Agarwood Extracts from Mature and Juvenile Aquilaria malaccensis. Int. J. Agric. Biol. 2017, 16, 644-648.

31. Sz, S.; Sárváry, A.; Cain, T.; Ádány, R. Method Validation for the Simultaneous Determination of Fecal Sterols in Surface Waters by Gas Chromatography-Mass Spectrometry. J. Chromatogr. Sci. 2006, 44, 70-76.

32. Adam, A.Z.; Tajuddin, S.N.; Sudmoon, R.; Chaveerach, A.; Abdullah, U.H.; Mahat, M.N.; Mohamed, R. Chemical Constituents and Toxicity Effects of Leaves from Several Agarwood Tree Species (Aquilaria). J. Trop. For. Sci. 2018, 30, 342-353. 
33. Kachlicki, P.; Piasecka, A.; Stobiecki, M.; Marczak, Ł. Structural Characterization of Flavonoid Glycoconjugates and Their Derivatives with Mass Spectrometric Techniques. Molecules 2016, 21, 1494. [CrossRef] [PubMed]

34. Zou, D.; Wang, J.; Zhang, B.; Xie, S.; Wang, Q.; Xu, K.; Lin, R. Analysis of Chemical Constituents in Wuzi-Yanzong-Wan by UPLC-ESI-LTQ-Orbitrap-MS. Molecules 2015, 20, 21373-21404. [CrossRef] [PubMed]

35. Son, S.-W.; Kim, H.-G.; Han, J.-M.; Lee, J.-S.; Choi, M.-K.; Lee, J.-S.; Son, C.-G. Anti-Melanoma Activity of Cynanchi atrati Radix Is Mediated by Regulation of NF-Kappa B Activity and pro-Apoptotic Proteins. J. Ethnopharmacol. 2014, 153, 250-257. [CrossRef] [PubMed]

36. Aromdee, C.; Pranakhon, R.; Pannangpetch, P. Effects of Iriflophenone 3-C- $\beta$-Glucoside on Fasting Blood Glucose Level and Glucose Uptake. Pharmacogn. Mag. 2015, 11, 82-89. [CrossRef]

37. Shan, L.; Wu, Y.; Yuan, L.; Zhang, Y.; Xu, Y.; Li, Y. Rapid Screening of Chemical Constituents in Rhizoma anemarrhenae by UPLC-Q-TOF/MS Combined with Data Postprocessing Techniques. Evid.-Based Complement. Altern. Med. 2017, 2017. [CrossRef]

38. Yu, Q.; Qi, J.; Yu, H.-X.; Chen, L.-L.; Kou, J.-P.; Liu, S.-J.; Yu, B.-Y. Qualitative and Quantitative Analysis of Phenolic Compounds in the Leaves of Aquilaria sinensis Using Liquid Chromatography-Mass Spectrometry. Phytochem. Anal. 2013, 24, 349-356. [CrossRef]

39. Qi, J.; Lu, J.-J.; Liu, J.-H.; Yu, B.-Y. Flavonoid and a Rare Benzophenone Glycoside from the Leaves of Aquilaria sinensis. Chem. Pharm. Bull. 2009, 57, 134-137. [CrossRef]

40. Feng, J.; Yang, X.-W.; Wang, R.-F. Bio-Assay Guided Isolation and Identification of $\alpha$-Glucosidase Inhibitors from the Leaves of Aquilaria sinensis. Phytochemistry 2011, 72, 242-247. [CrossRef]

41. Fabre, N.; Rustan, I.; Hoffmann, E.; Quetin-Leclercq, J. Determination of Flavone, Flavonol, and Flavanone Aglycones by Negative Ion Liquid Chromatography Electrospray Ion Trap Mass Spectrometry. Am. Soc. Mass Spectrom. 2001, 12, 707-715. [CrossRef]

42. Said, R.B.; Hamed, A.I.; Mahalel, U.A.; Al-Ayed, A.S.; Kowalczyk, M.; Moldoch, J.; Oleszek, W.; Stochmal, A. Tentative Characterization of Polyphenolic Compounds in the Male Flowers of Phoenix dactylifera by Liquid Chromatography Coupled with Mass Spectrometry and DFT. Int. J. Mol. Sci. 2017, 18, 512. [CrossRef]

43. Flamini, R. Recent Applications of Mass Spectrometry in the Study of Grape and Wine Polyphenols. ISRN Spectrosc. 2013, 2013. [CrossRef]

44. Tay, P.; Tan, C.; Abas, F.; Yim, H.; Ho, C. Assessment of Extraction Parameters on Antioxidant Capacity, Polyphenol Content, Epigallocatechin Gallate (EGCG), Epicatechin Gallate (ECG) and Iriflophenone 3-C- $\beta$-Glucoside of Agarwood (Aquilaria Crassna) Young Leaves. Molecules 2014, 19, 12304-12319. [CrossRef]

45. Li, T.; Li, F.; Liu, X.; Liu, J.; Li, D. Synergistic Anti-Inflammatory Effects of Quercetin and Catechin via Inhibiting Activation of TLR4-MyD88-Mediated NF-KB and MAPK Signaling Pathways. Phytother. Res. 2019, 33, 756-767. [CrossRef]

46. Cheng, A.-W.; Tan, X.; Sun, J.-Y.; Gu, C.-M.; Liu, C.; Guo, X. Catechin Attenuates TNF- $\alpha$ Induced Inflammatory Response via AMPK-SIRT1 Pathway in 3T3-L1 Adipocytes. PLoS ONE 2019, 14. [CrossRef]

47. Mena, P.; Sánchez-Salcedo, E.M.; Tassotti, M.; Martínez, J.J.; Hernández, F.; Rio, D.D. Phytochemical Evaluation of Eight White (Morus alba L.) and Black (Morus nigra L.) Mulberry Clones Grown in Spain Based on UHPLC-ESI-MSn Metabolomic Profiles. FRIN 2016, 89, 1116-1122. [CrossRef]

48. Álvarez-Fernández, M.A.; Cerezo, A.B.; Cañete-Rodríguez, A.M.; Troncoso, A.M.; García-Parrilla, M.C. Composition of Nonanthocyanin Polyphenols in Alcoholic-Fermented Strawberry Products Using LC-MS (QTRAP), High-Resolution MS (UHPLC-Orbitrap-MS), LC-DAD, and Antioxidant Activity. J. Agric. Food Chem. 2015, 63, 2041-2051. [CrossRef]

49. Vuković, N.; Vukić, M.; Đelić, G.; Kacaniova, M.; Cvijović, M. The Investigation of Bioactive Secondary Metabolites of the Methanol Extract of Eryngium amethystinum. Kragujev. J. Sci. 2018, 40, 113-129. [CrossRef]

50. Zhao, H.; Wang, J.; Xie, C.; Song, S.; Bai, G.; Luo, G. Study on Fingerprints of Different Organs of Arabidopsis thaliana by Using UPLC/ESI-Q-TOF MS. Asian J. Chem. 2013, 25, 3023-3029. [CrossRef]

51. Gu, D.; Yang, Y.; Abdulla, R.; Aisa, H.A. Characterization and Identification of Chemical Compositions in the Extract of Artemisia rupestris L. by Liquid Chromatography Coupled to Quadrupole Time-of-Flight Tandem Mass Spectrometry. Rapid Commun. Mass Spectrom. 2011, 26, 83-100. [CrossRef]

52. Rosso, M.D.; Panighel, A.; Vedova, A.; Gardiman, M.; Flamini, R. Characterization of Non-Anthocyanic Flavonoids in Some Hybrid Red Grape Extracts Potentially Interesting for Industrial Uses. Molecules 2015, 20, 18095-18106. [CrossRef] 
53. Mcnab, H.; Ferreira, E.S.; Hulme, A.N.; Quye, A. Negative Ion ESI-MS Analysis of Natural Yellow Dye Flavonoids-An Isotopic Labelling Study. Int. J. Mass Spectrom. 2009, 284, 57-65. [CrossRef]

54. Kang, J.; Price, W.E.; Ashton, J.; Tapsell, L.C.; Johnson, S. Identification and Characterization of Phenolic Compounds in Hydromethanolic Extracts of Sorghum Wholegrains by LC-ESI-MSn. Food Chem. 2016, 211, 215-226. [CrossRef]

55. Bhat, G.; Shawl, A.S.; Shah, Z.; Tantry, M. HPLC-DAD-ESI-MS/MS Identification and Characterization of Major Constituents of Iris crocea, Iris germanica and Iris spuria Growing in Kashmir Himalayas, India. J. Anal. Bioanal. Tech. 2014, 5. [CrossRef]

56. Justesen, U. Negative Atmospheric Pressure Chemical Ionisation Low-Energy Collision Activation Mass Spectrometry for the Characterisation of Flavonoids in Extracts of Fresh Herbs. J. Chromatogr. A 2000, 902, 369-379. [CrossRef]

57. Chen, G.; Li, X.; Saleri, F.; Guo, M. Analysis of Flavonoids in Rhamnus davurica and Its Antiproliferative Activities. Molecules 2016, 21, 1275. [CrossRef]

58. Wang, S.-L.; Hwang, T.-L.; Chung, M.-I.; Sung, P.-J.; Shu, C.-W.; Cheng, M.-J.; Chen, J.-J. New Flavones, a 2-(2-Phenylethyl)-4H-Chromen-4-One Derivative, and Anti-Inflammatory Constituents from the Stem Barks of Aquilaria sinensis. Molecules 2015, 20, 20912-20925. [CrossRef]

59. Chu, C.-W.; Li, W.-J.; Li, H.-T.; Huang, J.-C.; Chung, M.-I.; Chen, C.-Y. Flavonoids from the Flowers of Aquilaria sinensis. Chem. Nat. Compd. 2016, 52, 497-498. [CrossRef]

60. Grabsk, A.; Avincola, A.; Claus, T.; Porto, C.; Visentainer, J.; Pilau, E. Direct Incorporation of Ginger and Oregano Antioxidants in Canola Oil. J. Braz. Chem. Soc. 2016, 28, 995-1002. [CrossRef]

61. Liu, S.; Che, Y.; Wang, F.; Shang, Z.; Lu, J.; Dai, S.; Zhang, J.; Cai, W. Identification of Metabolites of $6^{\prime}$-Hydroxy-3,4,5,2' $4^{\prime}$-Pentamethoxychalcone in Rats by a Combination of Ultra-High-Performance Liquid Chromatography with Linear Ion Trap-Orbitrap Mass Spectrometry Based on Multiple Data Processing Techniques. Molecules 2016, 21, 1266. [CrossRef]

62. Yang, X.B.; Feng, J.; Yang, X.W.; Zhao, B.; Liu, J.X. Aquisiflavoside, a New Nitric Oxide Production Inhibitor from the Leaves of Aquilaria sinensis. J. Asian Nat. Prod. Res. 2012, 14, 867-872. [CrossRef]

63. Ito, T.; Kakino, M.; Tazawa, S.; Watarai, T.; Oyama, M.; Maruyama, H.; Araki, Y.; Hara, H.; Iinuma, M. Quantification of Polyphenols and Pharmacological Analysis of Water and Ethanol-Based Extracts of Cultivated Agarwood Leaves. J. Nutr. Sci. Vitaminol. 2012, 58, 136-142. [CrossRef]

64. Ito, T.; Kakino, M.; Tazawa, S.; Oyama, M.; Maruyama, H.; Araki, Y.; Hara, H.; Iinuma, M. Identification of Phenolic Compounds in Aquilaria crassna Leaves Via Liquid Chromatography-Electrospray Ionization Mass Spectroscopy. Food Sci. Technol. Res. 2012, 18, 259-262. [CrossRef]

65. Davis, B.D.; Needs, P.W.; Kroon, P.A.; Brodbelt, J.S. Identification of Isomeric Flavonoid Glucuronides in Urine and Plasma by Metal Complexation and LC-ESI-MS/MS. J. Mass Spectrom. 2006, 41, 911-920. [CrossRef]

66. MUN, Y.M. Chemical Constituents and Bioactivity of Selected Malaysian Plants. Ph.D. Thesis, Monash University, Melbourne, Malaysia, 2017.

67. Chen, D.; Bi, D.; Song, Y.-L.; Tu, P.-F. Flavanoids from the Stems of Aquilaria sinensis. Chin. J. Nat. Med. 2012, 10, 287-291. [CrossRef]

68. Xu, X.; Li, X.; Liang, X. Application of Ultra-Performance Liquid Chromatography Coupled with Quadrupole Time-of-Flight Mass Spectrometry in Identification of Three Isoflavone Glycosides and Their Corresponding Metabolites. Rapid Commun. Mass Spectrom. 2018, 32, 262-268. [CrossRef]

69. Gampe, N.; Darcsi, A.; Lohner, S.; Béni, S.; Kursinszki, L. Characterization and Identification of Isoflavonoid Glycosides in the Root of Spiny Restharrow (Ononis spinosa L.) by HPLC-QTOF-MS, HPLC-MS/MS and NMR. J. Pharm. Biomed. Anal. 2016, 123, 74-81. [CrossRef]

70. Münger, L.H.; Boulos, S.; Nyström, L. UPLC-MS/MS Based Identification of Dietary Steryl Glucosides by Investigation of Corresponding Free Sterols. Front. Chem. 2018, 6, 342. [CrossRef]

71. Naumoska, K.; Vovk, I. Analysis of Triterpenoids and Phytosterols in Vegetables by Thin-Layer Chromatography Coupled to Tandem Mass Spectrometry. J. Chromatogr. A 2015, 1381, 229-238. [CrossRef]

72. Perveen, S.; Al-Taweel, A. Introductory Chapter: Terpenes and Terpenoids. In Terpenes and Terpenoids; IntechOpen: London, UK, 2018; pp. 1-12.

73. Pandey, R.; Chandra, P.; Srivastva, M.; Arya, K.R.; Shukla, P.K.; Kumar, B. A Rapid Analytical Method for Characterization and Simultaneous Quantitative Determination of Phytoconstituents in Piper betle landraces Using UPLC-ESI-MS/MS. Anal. Methods 2014, 6, 7349-7360. [CrossRef] 
74. Heras, B.L.; Rodriguez, B.; Bosca, L.; Villar, A. Terpenoids: Sources, Structure Elucidation and Therapeutic Potential in Inflammation. Curr. Top. Med. Chem. 2003, 3, 171-185. [CrossRef]

75. Kim, J.-S.; Ha, T.-Y.; Ahn, J.; Kim, S. Analysis and Distribution of Esculetin in Plasma and Tissues of Rats after Oral Administration. Prev. Nutr. Food Sci. 2014, 19, 321-326. [CrossRef]

76. Eklund, P.C.; Backman, M.J.; Kronberg, L.Å.; Smeds, A.I.; Sjöholm, R.E. Identification of lignans by liquid chromatography-electrospray ionization ion-trap mass spectrometry. J. Mass Spectrom. 2007, 43, 97-107. [CrossRef]

77. Bartosińska, E.; Buszewska-Forajta, M.; Siluk, D. GC-MS and LC-MS Approaches for Determination of Tocopherols and Tocotrienols in Biological and Food Matrices. J. Pharm. Biomed. Anal. 2016, 127, 156-169. [CrossRef]

78. Lang, L.; Dong, N.; Wu, D.; Yao, X.; Lu, W.; Zhang, C.; Ouyang, P.; Zhu, J.; Tang, Y.; Wang, W.; et al. 2-Arylbenzo [b] Furan Derivatives as Potent Human Lipoxygenase Inhibitors. J. Enzym. Inhib. Med. Chem. 2016, 31 (Suppl. 4), 98-105. [CrossRef]

79. Sadeghian, H.; Jabbari, A. 15-Lipoxygenase Inhibitors: A Patent Review. Expert Opin. Ther. Pat. 2015, 26, 65-88. [CrossRef]

80. Chung, L.Y.; Soo, W.K.; Chan, K.Y.; Mustafa, M.R.; Goh, S.H.; Imiyabir, Z. Lipoxygenase inhibiting activity of some Malaysian plants Lipoxygenase inhibiting activity of some Malaysian plants. Pharm. Biol. 2009, 47, 1142-1148. [CrossRef]

81. Ngamwongsatit, P.; Banada, P.P.; Panbangred, W.; Bhunia, A.K. WST-1-Based Cell Cytotoxicity Assay as a Substitute for MTT-Based Assay for Rapid Detection of Toxigenic Bacillus Species Using CHO Cell Line. J. Microbiol. Methods 2008, 73, 211-215. [CrossRef]

(C) 2020 by the authors. Licensee MDPI, Basel, Switzerland. This article is an open access article distributed under the terms and conditions of the Creative Commons Attribution (CC BY) license (http://creativecommons.org/licenses/by/4.0/). 